\title{
Bilgi Benimseme Modeli Kapsamında Elektronik Ağızdan Ağıza Pazarlamanın Marka Güveni Aracılığı ile Marka Sadakatine Etkisi ve Çevrimiçi Tüketiciler Üzerine Bir Araştırma
}

\section{Dilara Erşen}

Araștırma Görevlisi

Yeditepe Üniversitesi

İktisadi İdari Bilimler Fakültesi İşletme Bölümü dilara.ersen@yeditepe.edu.tr Orcid: 0000-0003-1210-1426

\section{Nevin Karabıyık Yerden}

Doktor Öğretim Üyesi Marmara Üniversitesi Sosyal Bilimler Meslek Yüksekokulu Pazarlama ve Reklamclık Bölümü nkarabiyik@marmara.edu.tr Orcid: 0000-0003-1114-2672

\section{Mehmet Yaman Öztek}

Profesör Doktor Galatasaray Üniversitesi İktisadi İdari Bilimler Fakültesi İşletme Bölümü moztek@gsu.edu.tr Orcid: 0000-0002-1129-5145

\footnotetext{
1 Bu çalışma, Dr. Öğr. Üyesi Nevin KARABIYIK YERDEN danışmanlığında Dilara ERŞEN tarafından hazırlanan ve Galatasaray Üniversitesi Sosyal Bilimler Enstitüsü'nde kabul edilen "Elektronik Ağızdan Ağıza Pazarlama ile Marka Sadakati Arasındaki Iliş̧kide Marka Güveninin Aracı Rolü ve Bir Araştırma" başlıklı yüksek lisans tezinden türetilmiştir.
} 


\section{Abstract \\ The Effect of Electronic Word of Mouth on Brand Loyalty through Brand Trust within the Scope of Information Adoption Model: A Research on Online Consumers}

The criteria evaluated in the adoption of information vary from person to person. Therefore, in the electronic word of mouth (eWOM) concept which is examined by the information adoption model: information comprehensiveness, information relevance, information usefulness, source trustworthy, and homophily dimensions come into prominence. In this context, the perception and adoption criteria of customer reviews on online shopping sites, which are covered by eWOM, affect consumers' brand attitudes. In a highly competitive market environment, organizations aim to stand out among competitors by creating brand loyalty and brand trust. In line with this information, in the study, the mediating role of brand trust in the relationship between eWOM and brand loyalty was researched. In this research, the questionnaire technique, one of the quantitative research methods, was used. The research model was tested empirically, using a sample of 401 respondents who does Internet shopping from solely online shopping websites. Respectively reliability analysis, factor analysis, regression analysis, and Sobel Test were applied to the variables in the research. According to the analyses, eWOM has a positive effect on brand loyalty through a brand trust has found. Additionally, it has found that information comprehensiveness, which is one of the dimensions of eWOM, has more effect on brand loyalty and brand trust than other dimensions.

keywords: Electronic word of mouth, brand trust, brand loyalty, online consumer reviews

\section{Résume}

L'effet du bouche à oreille électronique sur la fidélité à la marque grâce à la confiance dans la marque dans le cadre du modèle d'adoption de I'information: une recherche sur des consommateurs en ligne

Les critères évalués lors de l'interprétation des informations reçues par les consommateurs varient d'une personne à l'autre. C'est pour cette raison que l'exhaustivité, la pertinence et l'utilité de l'information, ainsi que la fiabilité de la source et les dimensions de l'homophilie prennent de l'importance dans le marketing de bouche à oreille électronique (eWOM) qui est examiné selon le modèle d'adoption de l'information. Dans le cadre de eWOM, les critères de perception et d'adoption des avis clients sur les sites de vente et d'achat en ligne, influencent les attitudes des clients envers les marques. Au sein d'un marché hautement concurrentiel, les entreprises visent à se différencier de leurs concurrents en essayant d'instaurer une fidélité à la marque et une confiance en 
la marque. De ce fait, cette étude examine le rôle médiateur de la confiance en la marque dans la relation entre le eWOM et la fidélité à la marque. La recherche est réalisée par la technique de questionnaire qui fait partie des méthodes quantitatives. Le modèle de recherche fut testé empiriquement sur un échantillon de 401 personnes qui font des achats uniquement à partir des sites web de vente et d'achat en ligne. Au niveau des analyses, sont utilisés respectivement l'analyse de fiabilité, l'analyse factorielle, l'analyse de régression et un test Sobel sur les variables. Selon les analyses, il a été conclu qu'il y a une corrélation positive entre le eWOM et la fidélité à la marque; que la confiance en la marque joue un rôle de médiateur dans cette corrélation et que l'exhaustivité des informations, a une plus grande influence sur les variables par rapport aux autres dimensions de eWOM.

mots-clés: Bouche à oreille électronique, confiance de la marque, fidélite à la marque, avis des consommateurs en ligne

\section{Öz}

Tüketicilere ulaşan bilgilerin yorumlanmasında değerlendirilen kriterler kişiden kişiye farklılı göstermektedir. Bu sebeple bilgi benimseme modeline göre incelenen elektronik ağızdan ağıza pazarlamada (EAAP), bilgi kapsamlıı̆ıı, bilgi ilgi düzeyi, bilgi kullanışlıığı, kaynak güvenilirliği ve kaynakla olan demografik benzerlik boyutları ön plana çıkmaktadır. EAAP'nin kapsamına giren çevrimiçi alışveriş sitelerindeki tüketici yorumlarının algılanma ve benimsenme kriterleri, tüketicilerin markalara karşı tutumlarını etkilemektedir. Rekabetin yoğun olduğu pazar ortamında işletmeler, marka sadakati ve marka güveni yaratarak rakiplerinden farklılaşmayı amaçlamaktadır. Dolayısıyla çalışmada, çevrimiçi alışveriş sitelerinde EAAP'nin marka sadakati ile ilişkisinde, marka güveninin aracı rolü incelenmektedir. Araştırmada, nicel araştırma yöntemlerinden anket tekniği kullanılmıştır. Araştırma modeli, yalnızca çevrimiçi alışveriş sitelerinden alışveriş yapan 401 kişilik örneklem üzerinde test edilmiştir. Analiz kısmında değişkenlere sırasıyla güvenilirlik, faktör, regresyon analizi ve Sobel Testi uygulanmıştır. Yapılan analizler doğrultusunda EAAP ile marka sadakati arasında pozitif bir ilişkinin varlığına; bu ilişkide marka güveninin aracı etkiye sahip olduğuna ve bilgi kapsamlılı̆ının diğer EAAP boyutlarına kıyasla, ana değişkenleri en yüksek oranda etkilediği sonucuna ulaşılmıştır.

anahtar kelimeler: Elektronik ağızdan ağıza pazarlama, marka güveni, marka sadakati, çevrimiçi tüketici yorumları 


\section{Giriş}

Teknoloji ile birlikte ortaya çıkan internet, sağlamış olduğu birçok avantaj açısından insan hayatıyla bütünleşen bir hâl almıştır. İnternetin tüketiciler tarafından aktif kullanımının artması ise pazarlama alanında, tüketicilerin alışveriş yapma yöntemlerini değiştirmekle birlikte, marka ve ürünlerle ilgili farklı tüketici tecrübelerine kolay bir şekilde ulaşımasını sağlayan yönlendirici bir unsur haline gelmiştir. Kişilerin internet ortamında marka, ürün ve hizmetlerle ilgili düşüncelerini, deneyimlerini ve tavsiyelerini paylaşması, özellikle bu paylaşımların çevrimiçi alışveriş sitelerinde yer alan kullanıcı yorumları ile gerçekleşmesi, tüketicilerin marka güveni ve marka sadakatlerini etkilemeye başlamıştır. Pazar ortamındaki ürün ve marka çeşitliliğinin artmasıyla birlikte rekabetin yoğunlaşması, birçok markanın güven ve sadakat aracılığıyla rakip markalardan farklılaşmasını gerektirmiştir. Bu durumda, elektronik ağızdan ağıza pazarlamanın (EAAP) bir göstergesi olan tüketici yorumları, rekabet avantajını artırmada göz ardı edilemeyecek bir öneme sahip olmuştur. Günümüzde, ileri teknoloji vasıtası ile markalar hakkındaki paylaşımlar, çok hızlı bir şekilde, birçok internet kullanıcısına ulaşmaktadır. Sanal ortamda çeşitli yorumlara erişen tüketiciler, kendilerine ulaşan bilgileri belirli faktörlere göre değerlendirmekte ve bu yorumlardan tutumsal ve davranışsal olarak etkilenmektedirler. Tüketicilerin erişmiş oldukları bu bilgilerin, kendilerini nasıl etkilediği, pazarlama yöneticileri açısından önemli bir durum olarak değerlendirilmektedir. Bu etkilerin çözümlenmesinde bilgi benimseme modeli önemli bir araç olarak kullanılabilmektedir. Bu gerekçe ile çalışmada EAAP kavramı, kullanıcılara ulaşan bilgilerin niteliklerinin analiz edilmesi açısından, bilgi benimseme modeline göre belirlenen alt boyutlarla incelenmiştir. Bilgi benimseme modeli, kişilerin kendilerine ulaşan bilgileri nasıl algıladıklarını ve bu bilgilerin internet ortamındaki platformlardaki iletişimlerde, kişilerin niyet ve davranışlarını nasıl değiştirdiklerini anlamaya yönelik olarak geliştirilmiş bir modeldir. EAAP'nin araçları bloglar, sosyal medya siteleri, e-posta, haber grupları, sohbet odaları, anlık mesajlaşma ve çevrimiçi alışveriş sitelerindeki tüketici yorumlarıdır (Litvin vd., 2008, s. 462). Çalışmada ise tüketicilerin alışveriş dinamiklerinin çevrimiçi ortama kayması, Türkiye'de 2019 yılındaki e-ticaret işlemlerinin 2018 yılına göre Türk Lirası bazında \%42 büyümesi (TUBISAD, 2019), 8.000 üzeri sanal mağazanın 5 milyondan fazla sipariş alması (IdeaSoft, 2019) ve bu ortamlardaki tüketici yorumlarının öneminin gitgide artması sebebi ile, yalnızca çevrimiçi alışveriş sitelerindeki tüketici yorumları seçilerek araştırma yapılmıştır. Çevrimiçi alışveriş sitelerinde yer alan yorumların tüketiciler tarafından belirli değerlendirme kriterlerine sahip olması, yorumlar aracılığıyla verilen tavsiyelerin benimsenmesini etkileyen unsurların ölçülmesini sağlayan bilgi benimseme modelinin kullanılmasını gerektirmektedir. Bu çalışmada EAAP, bilgi benimseme modeline göre belirlenmiş olan bilgi kapsamlıı̆̆, bilgi ilgi düzeyi, kullanışlıık, yorum paylaşan kaynağın güvenilirliği ve yorum okuyucusuyla olan demografik benzerlik boyutlarının kullanımıyla, tüketicilerin hakkında yorum yapılan markaya karşı duymuş oldukları güven ve sadakat ilişkisinin incelenmesi amaçlanmaktadır. Ayrıca marka sadakatini oluşturmada etkili bir kavram olan marka güveni ise araştırma modelinde aracı değişken olarak yer almaktadır. Araştırma- 
da, betimsel araştırma kapsamında nicel araştırma yöntemi kullanılmakla birlikte, örnekleme yöntemi olarak kolayda örneklem seçilmiş ve anket tekniği ile veri toplanmıştır. Bu çalışma, çevrimiçi alışveriş deneyimi olan 18-60 yaş tüketiciler üzerinde gerçekleştirilmiştir. Araştırmanın kısıtlarını, zaman, maliyet ve çevrimiçi alışveriş deneyimi olan tüketiciler oluşturmaktadır. Araştırmada 401 kullanılabilir anket üzerinden toplanan veriler analiz edilmiştir. Araştırmanın analizlerinde SPSS (Statistical Package for Social Sciences) for Mac 20.0 paket programı kullanılmıştır. Analiz kısmında değişkenlere sırasıyla güvenilirlik, faktör ve regresyon analizi ile aracıı iliş̧kisinin anlamılı̆̆ının belirlenmesini sağlayan Sobel Testi uygulanmıştır. Verilerin analizi ile, bilgi benimseme modeli baz alınarak incelenen EAAP kavramının marka sadakatini etkilediği ve marka güveninin bu ilişkide kısmi aracı role sahip olduğu sonucuna varılmıştır. Yapılan analizler ile ayrıca EAAP boyutlarından bilgi (yorum) kapsamlıı̆̆ının, diğer boyutlara kıyasla marka sadakatini ve marka güvenini daha fazla etkilediği ortaya çıkmıştır.

\section{Elektronik Ağızdan Ağıza Pazarlama Kavramı}

Elektronik ağızdan ağıza pazarlama kavramının (EAAP) temelinde, kişilerarası iletişim yer almaktadır. Kişilerarası iletişimin pazarlama bilim dalı kapsamına girmesiyle birlikte ağızdan ağıza pazarlama (AAP) kavramı, bu kavramın sanal ortama taşınmasıyla ise EAAP kavramı gelişmiştir.

AAP, kişilerin birbirleriyle kurmuş oldukları sözlü iletişimin konusunun belirli ürün, hizmet ve marka hakkında olması ve bu iletişimin herhangi bir reklam amacı gütmemesi şeklinde tanımlanmaktadır (Arndt, 1967, s. 291). Arndt (1967)'e göre AAP, katıımcıların sözlü iletişimini içermekte ve mesajı gönderen taraf ile mesajın alıcısının aynı anda birbirleriyle etkileşim halinde olma durumunu gerektirmektedir. Bu ise eş zamanlı senkronizasyon olarak adlandırımıştır (Arndt, 1967, s. 292).

AAP tüketicilerin ürün, hizmet ve markalar hakkındaki inançlarını, tutumlarını ve satın alma davranışlarını etkileyerek, sosyal etkinin kritik bir parçası haline gelmiştir (Arndt, 1967, s. 292; Daugherty ve Hoffman, 2014, s. 82; Herold vd., 2016, s. 80; Li ve Wu, 2018, s. 3, Ransbotham vd., 2019, s. 773). Somut ürünlerin yanı sıra hizmetler hakkında gerçekleşen AAP faaliyetleri de tüketiciler için büyük önem taşımaktadır. Bunun sebebi ise hizmetlerin deneyimlenmeden yorumlanamaması ve somut ürünler gibi dokunup incelenemememesidir (Jalilvand ve Samiei, 2012, s. 592, Liu vd., 2019, s. 381).

Yapılan bir araştırmaya göre tüketicilerin \%92'si televizyon, radyo ve gazete gibi geleneksel reklam araçlarına oranla aileleri, arkadaşları ve tanıdıklarıyla kurmuş oldukları AAP ile edindikleri bilgilere daha çok güvenmekte; AAP vasıtasıyla yapılan satışlar diğer tutundurma faaliyetlerine oranla 5 kat daha fazla olmakta; tüketicilerin \%88'i ise çevrimiçi tüketici yorumlarına güvenmektedir. Ek olarak pazarlama yöneticilerinin \%64'ünün AAP'yi, pazarlama yöntemleri içinde en etkili yöntem olarak gördükleri ortaya çıkmıştır (Review42, 2019). 
Internet, bilgi ve fikirlerin işletmeden tüketiciye ve tüketiciden tüketiciye aktarılmasında bilgi sağlayıcılara ve tüketicilere birçok platform seçeneği sunmaktadır. "We Are Social" 2019 raporuna göre, dünyada 4.39 milyar kişi internet kullanmaktadır ve kullanıcılar internet ortamında günde yaklaşık yedi saat çevrimiçi olmaktadırlar. Tüketicilerle mail, reklam, çevrimiçi tartışma grupları, sosyal medya platformları, çevrimiçi alışveriş siteleri gibi aracılarla iletişim kuran işletme sayısı 30 milyonu geçmektedir (We Are Social, 2019).

EAAP, tüketicilerin sanal ortamda belirli bir ürün, marka ve hizmet hakkında olumlu veya olumsuz bilgilere ulaşmasını sağlayan ve böylece satın alma kararlarındaki risk düzeyini minimum seviyeye indirmeyi amaçlayan bir kavram olarak tanımlanmaktadır (Blazevic vd., 2013, s. 304; Ransbotham vd., 2019, s. 774). Geleneksel $A A P^{\prime}$ de mesaj göndericisi ve alıcısı arasında yüz yüze etkileşim gerekli iken EAAP'de, aralarındaki sosyal bağların zayıf olduğu tarafların birbirleriyle kurmuş oldukları iletişim yeterli olmaktadır (Chu vd., 2018, s. 3). EAAP'nin sağlamış olduğu avantajlar çeşitlilik göstermektedir. Tüketicilerin aranılan bilgiye ulaşma maliyetleri, başka bir deyişle araştırma maliyetleri EAAP sayesinde önemli ölçüde azalmaktadır (Chen ve Xie, 2008, s. 488; Gkoumas, 2019, s. 2). Ayrıca tüketicilerin tarafsı içeriklere daha fazla güveniyor olması da EAAP'nin, satın alma kararlarındaki etkisini göstermektedir (Herold vd., 2016, s. 80; Erkan ve Evans, 2018, s. 623; Liang vd., 2018, s. 80).

EAAP'de, internet ortamında yapılan paylaşımlar hızlı bir şekilde farklı tüketicilere ulaşabilmekte ve coğrafi sınırlar ortadan kalkmaktadır. Paylaşılan içerikler, kullanııılar tarafından istenilen zamanda ve istenilen sıkıkta görüntülenebilmektedir. Ek olarak sanal ortamda internet kullanıcıları tarafından paylaşılan yorumların içeriği bozulmamakta, ana kaynaktan çıkan paylaşım aynı şekliyle farklı kullanıcllara ulaşmaktadır (Ferris Costa, 2011, s. 22; Huang vd., 2011, s. 1278, Zhao vd., 2019, s. 130). Kişilerin internet ortamındaki anonim kullanıcılar ile gerçekleştirdikleri EAAP iletişimi, tüketicilerin satın alma niyetlerini, tanıdık kullanıcılar ile gerçekleştirilen EAAP iletişimine göre daha çok etkilemektedir (Erkan ve Evans, 2018, s. 623).

Tüketicilerin EAAP iletişimi ile birbirleriyle etkileşimde bulunması, bilgi alma ve paylaşma konularında kendi intiyaçlarını tatmin etme isteklerinin var olmasından kaynaklanmaktadır (Lovett vd., 2013, s. 440). Tüketicilerin bu isteklerini yerine getirmeleri, kaliteli bilgi ve değerli ürün içeriklerine bağlıdır. Sağlanan bu nitelikler aracılığıyla tüketiciler daha sağlıklı satın alma kararı vermekte ve bilgi paylaşımı yapan kişiler de paylaşmış oldukları içeriklerin yararlı olduğunu fark ederek, aynı platformu kullanan tüketicilere fayda sağladıklarını hissetmektedirler (Kreis ve Gottschalk, 2015, s. 408; Erkan ve Evans, 2018, s. 627).

EAAP'nin önemi, dünyanın en değerli markası olan (Kantar, 2019, s. 9) e-ticaret sitesi Amazon'un kurucusu Jeff Bezos tarafından şu şekilde ifade edilmektedir: "Eğer fiziksel dünyada tüketicilerinizi memnun etmezseniz, tüketici bu tec- 
rübesini altı arkadaşı ile paylaşır. Fakat tüketicilerinizi internet ortamında memnun etmezseniz, bu durum 6.000 kişiye hızla ulaşır" (Bezos'tan aktaran Lake, 2013).

Bu çalışmanın bağımsız değişkenini oluşturan EAAP'nin analizi bilgi benimse modeli kullanılarak gerçekleştirildiğinden, bilgi benimseme modelinin detaylandırıması intiyacı ortaya çıkmaktadır.

\section{EAAP ve Bilgi Benimseme Modeli}

EAAP iletişiminde kaynaktan çıkan mesaj, herkese aynı içerikte ulaşmasına rağmen mesajın içeriği farklı kişiler tarafından farklı şekillerde değerlendirilmektedir. Bu sebeple internette paylaşılan sayısız içerikten hangilerinin tüketiciler tarafından değerlendirilmeye alınacağı ve bilgi benimseme kriterlerinden hangilerinin tüketiciler açısından önem teşkil ettiği, üzerinde durulması gereken bir konu haline gelmiştir. Sussman ve Siegal (2003, s. 50) tarafından geliştirilen Bilgi Benimseme Modeli, kişilerin bilgi benimseme sürecindeki kriterlerin ortaya koyulmasını sağlayarak, tüketicilerin daha iyi anlaşılmasına olanak vermektedir.

Bilgi benimseme modeli, bilgisayar ortamlı iletişim platformlarında yer alan bilgilerin kişiler tarafından nasıl algılandığını, kişilerin niyetlerini ve davranışlarını nasıl etkilediğini ortaya çıkarmaya yönelik olarak oluşturulan bir model şeklinde açıklanmaktadır. Model, Şekil 1'de gösterilmektedir. Bilgi benimseme modeli, teknoloji kabul modeli ve çift süreçli bilgi etkisi teorilerinden "detaylandırma olasılık modeline" dayanmaktadır. Teknoloji kabul modeli literatürde önemli ölçüde kabul gören bir teori olmasına rağmen, açıklayıcı gücü sınırlıdır. Model genel olarak bilgi sistemlerine ve kişilerin bilgisayar kullanımına odaklanırken, sosyal süreci göz ardı etmektedir (Riffai vd., 2012, s. 240). Bilgi benimseme modelinin çıkış noktalarından bir diğeri olan detaylandırma olasılık modeli ise alıcıların mesaj aracılığıyla ulaşan bilgilerden nasıl etkilendiğini incelediğinden, kişilerin tutumlarındaki değişikliği ve ikna edici iletişimin etkisi altında yatan süreci açıklamak için kullanılmaktadır (Petty ve Cacioppo, 1986, s. 126). Detaylandırma olasılık modeline göre kişilerin iletişim sürecini yönlendirebileceği, merkezi ve çevresel olmak üzere, iki farklı yol vardır. Bahsi geçen yolların ikisi de zihinsel bir süreç tarafından karakterize edilmiştir. Merkezi yol, düşünmenin kontrol edilebilen, derin ve sistematik bir yoludur. Diğer bir yandan çevresel yol ise otomatik, merkezi olmayan ve yüzeysel bir düşünce yoludur (Gass ve Seiter, 2016, s. 36). 
Şekil 1. Bilgi Benimseme Modeli

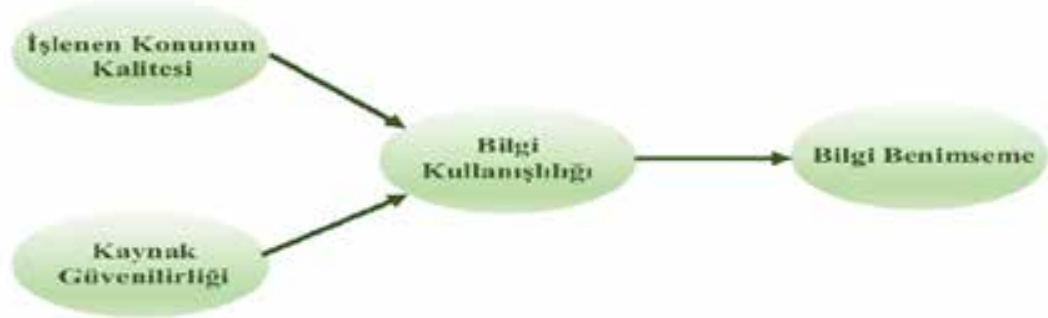

Kaynak: Sussman, S.W. and Siegal, W.S. (2003), "Informational influence in organizations: an integrated approach to knowledge adoption", Informational

Systems Research, Vol. 14 No. 1, pp. 47-65.

Yapılan araştırmalar, bilgi benimseme modeli, teknoloji kabul modeli ve detaylandırma olasılık modelinin birbirine entegre edildiğini göstermektedir. Bilgi benimseme modelinde, işlenen konunun kalitesi ve mesajın çıktığı kaynağın güvenilirliği, bilgi kullanışlıı̆̆ını etkilemekte olup bilgi kullanışlıı̆ı ise bilgi benimseme davranışına etki etmektedir. Tüketicilerin çevrimiçi ortamlardaki davranışlarını inceleyen farklı modeller yer almakla birlikte, bilgi benimseme modeli bu alanda en son geliştirilen model olduğu için güncel çalışmalarda sıklıkla kullanılmaktadır (Filieri ve Mcleay, 2014, s. 44).

Bilgi benimseme modelinde işlenen konunun kalitesi, bilginin ikna edici gücünü ölçmektedir. Kavram, literatürde bilgi kapsamılığı, bilgi ilgi düzeyi, bilginin içeriği ve doğruluğu gibi farklı alt boyutlar aracılığıyla ölçülmüştür (Doll vd., 1988, s. 262). İlerleyen zamanlarda bahsi geçen boyutlara, eksiksizlik, kişiselleştirme, çeşitlilik gibi yeni boyutlar da eklenmiştir (Watts ve Zhang, 2008, s. 86). Kaynak güvenilirliği ise, mesaj alıcısının mesajı gönderen kaynağın güvenilirliğini nasıl algıladığını ölçen kavram olarak tanımlanmaktadır (Chaiken, 1980, s. 754). Yapılan araştırmalara göre kaynak güvenilirliği yüksek olan içerikler, tüketicilerin çevrimiçi bilgileri işleme süreçlerini geliştirmekte ve tüketici davranışlarına etki etmektedir (İsmagilova vd., 2019, s. 4). Kaynak güvenilirliği de literatürde, kaynağın güvenilir, inanılır ve demografik açıdan mesaj alıcısına benzer olması şeklindeki boyutlar aracılığıyla belirlenmektedir (Petty ve Cacioppo, 1986, s. 18). Modelde yer alan bilgi kullanışlılı̆ı ise kullanıcının kendine ulaşan bilgileri kullanışlı hissetme derecesini ifade etmektedir. Modelde yer alan bilginin kullanışlıı̆ı değişkeni, bilgi benimse davranışını önemli ölçüde etkilemektedir (Coursaris ve Van Osch, 2016, s. 23). Kişi kendisine ulaşan bilginin ne kadar çok işine yarayacağını düşünürse, kullanıcının bilgiyi kendine uyarlaması ve benimsemesi de bir o kadar kolay olmaktadır.

Tüketiciler, internet ortamında bilgi araştırması yaptıkları marka, ürün ve hizmetler hakkında ulaştıkları ve kayda değer olduğunu düşündükleri bilgiler ışığında, satın alma davranışlarını yönlendirmektedirler (İsmagilova vd., 2019, s. 
1). Modelde yer alan bilgi benimseme değişkeni ise kişilere ulaşan bilgilerin, kişi davranışlarına ne oranda yansıdığı anlamına gelmekte olup kişilerin kendilerine ulaşan bilgileri amaç odaklı karar vermede kullanıp kullanmayacaklarını açıklamaktadır (Pitta ve Fowler, 2005, s. 268). Herhangi bir tüketicinin satın almak istediği ürünün özellikleri ve markası gibi konular hakkında araştırma yaparak edinmiş oldukları bilgilerin kararlarını etkileme derecesi, bilgiyi benimseme seviyeleri ile ölçülmektedir (İsmagilova vd., 2019, s. 2). Literatürde, EAAP'nin etkilerinin ölçülmesinde, sanal ortamda yer alan bilgilere yönelik olarak bilgi benimseme modelinin kullanılabilecek önemli bir model olduğuna vurgu yapılmaktadır (Cheung vd., 2008, s. 231). Bu çalışmada çevrimiçi alışveriş sitelerindeki tüketici yorumları, bilgi benimseme modeli kapsamında belirlenen alt boyutlar aracıı̆ğıla incelenmiştir. EAAP'de en fazla kullanılan araçlardan biri ise web siteleri ve tüketici yorumlarıdır. Bu sebep ile web siteleri ve tüketici yorumlarının EAAP içerisinde açıklanmasında fayda görülmektedir.

\section{Web Siteleri ve Tüketici Yorumları}

Mesaj göndericisi ve mesaj alıcısı arasındaki iletişimi sağlayan geleneksel AAP kanalları, internetin kullanımıyla birlikte sanal ortama taşınmıştır. Teknolojinin ortaya çıkarmış olduğu bu kanallar, sosyal medya siteleri/uygulamaları, bloglar, e-posta, anlık mesajlaşma, haber grupları, web sitelerindeki tüketici yorumları olarak örneklendirilebilmektedir (Litvin vd., 2008, s. 462).

Web siteleri, kullanıcılar arası eş zamanlı etkileşimi gerektirmemekle birlikte, bir kişiden gönderilip birçok kişiye ulaşan iletilerin yer aldığı sanal ortam olarak tanımlanmaktadır. Etkili bir web sitesi, geleneksel reklamcılık gibi yalnızca bilgi paylaşma amacı için değil aynı zamanda ürün, marka ve hizmet ile ilgili bilgi edinme ve web sitesini ziyaret etme hissi oluşturmak için de kullanılmaktadır. Ayrıca web sitelerinden ürün satışları gerçekleşmekte, tüketiciler zamanla fiziksel mağaza alışverişinden, internet ortamından alışverişe yönlenmektedirler (Clare vd., 2018, s. 825).

Yapılan araştırmalara göre, 19 - 34 yaş aralığındaki tüketicilerin \%91'i kişisel tavsiyelere güvendikleri kadar, internet üzerinden yapılan tüketici yorumlarına güvenmekte olup, tüketicilerin \%97'si satın alma kararlarını vermeden önce internet üzerinden marka/ürün ve hizmetler hakkında yapılmış olan yorumları okumaktadırlar. Ek olarak tüketiciler, yorumları ve değerlendirmeleri iyi olan markaların web sitelerinde \%31 oranında daha fazla zaman geçirmektedirler (BrightLocal, 2018). Bununla birlikte internet ortamındaki yorumların kapsamlılığı ve konu ile ilgili olma derecesi, çevrimiçi tüketici davranışlarını yüksek oranda etkilemektedir (Hussain vd., 2017, s. 101). Ayrıca tüketiciler yapmış oldukları ve okudukları yorumlar ile kendilerini çevrimiçi topluluklara ne kadar bağlı hissederlerse ve yapılan yorumlara markalar tarafından ne kadar aktif bir şekilde geri dönüş sağlanırsa, marka tutumları ve satın alma niyetleri de tüketici yorumlarından önemli ölçüde etkilenecektir (Yu vd., 2012, s. 733; Bhandari ve Rodgers, 2018, s. 135). 
Günümüzde tüketicilerin bir ürünü satın almadan önce, çevrimiçi alışveriş sitelerindeki yorumları okumaları klasik bir davranış haline gelmekle birlikte (Hussain vd., 2017, s. 101), ürün, marka ve hizmet hakkında yapılan pozitif ve negatif yorumlar tüketicilerin kararlarını ve davranışlarını etkilemektedir. Ek olarak tüketiciler, sanal ortamda okumuş oldukları yorumlar ışığında ürünlerin markalarına karşı belirli bir tutum geliştirmektedir. Bu tutumlar ise tüketicilerin satın alma niyetlerini şekillendirmektedir (Kudeshia ve Kumar, 2017, s. 310). Tüketici tutumu ise marka güveni kavramı ile yakından ilgili olarak değerlendirilmektedir.

\section{Marka Güveni Kavramı}

Marka, bir üreticinin ürününü diğer üreticilerin ürünlerinden ayırt etmek için kullanılan bir isim, sembol ya da bunların kombinasyonudur (Business Dictionary, 2010). Ürünlerin birbirinden ayırt edilmesini sağlayan özellikler, performansla ilgili somut yapıdaki fiziksel ve fonksiyonel unsurlar olabilmekle birlikte soyut yapıdaki duygusal ve sembolik özellikler de olabilmektedir. Marka, eski İskandinav kelimelerinden biri olan "brandr" kelimesinden türemekte olup "yakmak" anlamına gelmekte ve canlı hayvan sahiplerinin, kendi hayvanlarını tanımlamalarını sağlayacak olan işaretlemeler olarak karşımıza çıkmaktadır. Amerikan Pazarlama Derneği'nin tanımına göre marka, "bir satıcının veya bir grup satıcının kendi ürün ve hizmetlerini, rekabet içerisinde oldukları ürün ve hizmet sağlayıcılarından ayırmak için kullandıkları isim, terim, işaret, sembol veya bu unsurların farklı kombinasyonlarıdır" (1960).

Kişilerin hayatlarının eskiye göre daha karmaşık, yoğun ve zamanla yarışıyormuşçasına hızı ilerlemesi, tüketicilerin markalar sayesinde hangi ürünü satın alacaklarını belirleme süreçlerini hızlandırmakta ve üstlenecekleri riski azaltmaktadır (Suri ve Monroe, 2003, s. 95). İşletmeler için marka, kendilerini temsil etme imkânı sunan aracılar olarak işlev görmektedir. Tüketiciler için ise seçim yapmalarını kolaylaştırma, belirli bir kalite seviyesinin altına düşmeme, riski azaltma ve güveni artırma gibi kritik özellikler sunmaktadır. Ayrıca marka, bir işletmeye ait olan ürünün kendine has, taklit edilmesi istenmeyen özelliklerini de korumaktadır (Kotler ve Keller, 2009, s. 242).

Güven kavramı ise sosyal psikoloji alanında, kişilerarası etkileşimin verimli bir şekilde gerçekleşmesini sağlayan unsur olarak incelenmeye başlanmıştır. Daha sonrasında birçok çalışmanın konusu olmuş ve iletişimden yönetime, liderlikten oyun teorisine, psikolojiden performans değerlendirmeye kadar farklı alanlarda kendini gösteren bir kavram olarak ele alınmıştır. Güven kavramı literatürde, kişiliğe özgü davranış, inanç, sosyal yapı ve davranışsal niyet gibi farklı şekillerde yer almakla birlikte, kişiler arası iletişimde güven, büyük bir öneme sahip olmaktadır. Kavram ayrıca, güven duyulan tarafa karşı savunmasız olma eğilimi ve bir kişinin diğer kişinin sözüne güvenebileceği genel bir beklenti hali şeklinde de tanımlanmaktadır (Mayer vd., 1995, s. 710). Güven, etkileşim halinde bulunan tarafların birbirlerinin dürüstlüğüne ve doğruluğuna inandığı ortamlarda oluşmaktadır. 
Marka güveni, tüketicilerin, markanın taahhütlerini yerine getirme yeteneklerine inanma durumu olarak tanımlanmaktadır (Chaudhuri ve Holbrook, 2001, s. 83). Ayrıca marka güveni, tüketicilerin markaya karşı olan beklentilerinin geçerli, tatmin edici, dürüst ve sorumluluk sahibi bir şekilde karşılanması olarak da açıklanmaktadır (Delgado-Ballester ve Manuera-Alemân, 2001, s. 1242). Marka güveni, literatürde, 2000'li yılların başında ayrıntılı bir şekilde incelenmeye başlamıştır (Delgado-Ballester vd., 2003, s. 36). Morgan ve Hunt'a göre (1994, s. 22), marka güveni, satın alınamamakta ve taklit edilememektedir. Riskin yüksek ve marka çeşitliliğinin çok olduğu pazar ortamında tüketiciler, kendileri için güven teşkil eden markalara inanmaktadırlar (Veloutsou, 2015, s. 407).

Marka güveni oluşturmak ne kadar zorsa, güvenin zedelenmesi de bir o kadar kolaydır. Özellikle geleneksel AAP ve EAAP'de kişilerin olumlu ve olumsuz deneyimlerinin hızlı bir şekilde yayılıyor oluşu, marka güveninin hasar görmemesi açısından üzerinde durulması gereken bir konu olarak ortaya çıkmaktadır (Zboja ve Voorhees, 2006, s. 383). Marka güveni, kişilerin daha önceden yaşamış oldukları tecrübeler ışığında şekillenmekle birlikte, art arda yaşanan tecrübelerin olumlu olması, tüketicilerin marka ile kurmuş oldukları güven bağlarını her seferinde daha da sağlamlaştırmaktadır (Rempel vd., 1985, s. 97).

Pazarlama araçları içerisinde en etkili kavramlardan biri olan EAAP, tüketicilerin markaya dair farkındalıklarını, marka imajını, tüketici tutum ve davranışlarını büyük ölçüde etkilemektedir. Literatürdeki birçok araştırma da EAAP'nin etkilediği birçok alan üzerinde durmaktadır (Kudeshia ve Kumar, 2017, s. 310; Elseidi ve El-baz, 2016, s. 268; Krishnamurthy ve Kumar, 2018, s. 153).

Marka güveninin boyutları güven ve niyet olmak üzere ikiye ayrılmaktadır. Güven boyutu, tüketicilerin markanın vermiş olduğu sözleri tutacağına dair inancı ifade etmekte olup yapısı teknik ve yetkinlik temellidir (Andaleeb, 1992, s. 4; Morgan ve Hunt, 1994, s. 22; Doney ve Cannon, 1997, s. 37). Bir başka deyişle, markanın tüketici ihtiyaçlarını karşılayabileceğine ve tüketicileri memnun edeceğine yönelik algıdır. Ayrıca, markanın tüketici taleplerine cevap vermesinde gerekli olan kapasiteye sahip olduğuna dair varsayımdır. Marka, sağlamış olduğu güven ile gelecekte sergileyeceği performansın sözünü vermektedir ve verilen söz tutulduğunda tüketiciler, yeniden satın alma davranışı sergilemektedirler. Marka güveni boyutlarından niyet ise satın alınan ürün ile ilgili beklenmeyen bir problemin ortaya çıkması durumunda, markanın kendilerine yardımcı olacağına dair tüketici inancıdır. Niyet boyutu, güven boyutu ile kıyaslandığında, daha soyut bir kavram olarak karşımıza çıkmaktadır. Sebebi ise hissi ve duygusal bir kökene dayanmasıdır (Delgado-Ballester ve Munuera-Alemân, 2001, s. 1243). Yapılan araştırmalar marka güveni ile marka sadakati arasında pozitif yönlü ve anlamlı bir ilişkinin olduğunu desteklemektedir (Sirdeshmukh vd., 2002, s. 15; Mabkhot vd., 2017, s. 77). 


\section{Marka Sadakati Kavramı}

Marka sadakati kavramı ilk olarak 1923 yılında "marka ısrarı" olarak ortaya çıkmakla birlikte tüketicilerin, herhangi bir acil durum olmadığı koşullarda, sürekli olarak aynı markanın ürününü satın alacaklarını ifade etmektedir (Copeland, 1923, s. 283). Hakkında birçok araştırma yapılan marka sadakati kavramının, 1960 'ı yıllara kadar yapılan tanımlamalarında belirli eksiklikler olduğu fark edilmiştir ve bu eksikliklerin marka sadakatinin yalnızca tüketicilerin ürünleri satın alma miktarıyla ölçülmesinden kaynaklandığı sonucuna varılmıştır (Brody ve Cunningham, 1968, s. 51; Farley, 1963, s. 299). Tüketicilerin belirli markanın ürünlerini satın alma davranışı, marka sadakatinin davranışsal yönünü açıklamaktadır (Tucker, 1964, s. 32; Frank vd., 1965, s. 251). Fakat zamanla, marka sadakatinin davranışsal yönüne ek olarak tutumsal yönünün de ele alınması gerektiğine vurgu yapılmıştır (Day, 1969, s. 30). Tutumsal marka sadakati, kişilerin tekrar eden satın alma davranışlarının, bilinçli bir değerlendirme sonrasında gerçekleştirilmesini ifade etmektedir ( $\mathrm{Hu}$ ang ve $Y u, 1999$, s. 525). Dolayısıyla tüketicinin marka sadakati yalnızca tutumsal açıdan veya yalnızca davranışsal açıdan değil, tutumsal ve davranışsal faktörlerin birbiriyle bütünleşmiş şekli olarak ele alınmalıdır. Marka sadakatinin varlığından bahsedilebilmesi için, tüketiciler tarafından tutumsal açıdan verilen kararların, davranışsal açıdan satın alma çıktılarına dönüşmesi gerekmektedir. Literatürde marka sadakati kavramı en kapsamlı haliyle ilk olarak Jacoby ve Kyner (1973, s. 2) tarafından gelişigüzel gerçekleşmeyen ve tarafl;; satın alma gibi davranışsal sonuçları ortaya çıkaran; zamanla oluşan; karar verme süreçleri sonucunda meydana gelen; birçok marka alternatifi arasından belirli bir veya birkaç markanın seçimiyle gerçekleşen ve değerlendirme gibi psikolojik faktörleri içeren faaliyetler şeklinde tanımlanmıştır.

Ayrıca kavram, tüketicilerin gelecekteki satın alma faaliyetlerinde, tekrar eden satın alma davranışlarına bağlı olmakla birlikte, kişilerin karşılaşacakları farklı durumlarda, sürekli olarak ürünlerini satın aldıkları markadan vazgeçmeyeceklerine dair vermiş oldukları söz olarak da tanımlanmıştır (Oliver, 1999, s. 34). Marka sadakati özellikle hizmet sunan işletmeler için kritik bir performans ölçütü olmakla birlikte (Chaudhuri ve Holbrook, 2001, s. 81), tekrar eden satın alım faaliyetlerini gerçekleştirmesinden dolayı pozitif ağızda ağıza pazarlama içeriklerinden önemli ölçüde etkilenmekte ve nakit akışını artırmaktadır (Aksoy vd., 2013, s. 74). Aynı zamanda tüketicilerin fiyat hassaslığını (Chaudhuri ve Holbrook, 2001, s. 84), sermaye yatırımlarını, işletme maliyetlerini azaltmakta (Oliver, 1999, s. 33) ve kârıı̆ı̆ı artırmaktadır (Hayes, 2008, s. 25). Bu gerekçeler kapsamında, EAAP ile marka sadakati arasında bir ilişki olduğu, bu ilişkide ise marka güveninin aracı bir role sahip olduğu düşünülmektedir. 


\section{Araştırmanın Metodolojisi}

\section{Araştırmanın Konusu ve Amacı}

Bu araştırmanın amacı bilgi benimseme modeli kapsamında EAAP ile marka sadakati ilişkisinde marka güveninin aracı rolünü ortaya koymaktır. Bu amaç doğrultusunda araştırma, bilgi benimseme modeli, EAAP, marka güveni ve marka sadakati konularını kapsamaktadır. Çalışma sınırları içinde, çevrimiçi alışveriş tüketiciler yer almaktadır.

\section{Araştırmanın Yöntemi ve Tekniği}

Bu çalışma, betimsel araştırma niteliğinde olup, araştırmada nicel araştırma yöntemlerinden anket tekniği kullanılmaktadır. Betimsel araştırmalar, mevcut bir durumun tanınmasına ve tahmin edilmesine yöneliktir. Değişkenler arasındaki ilişkileri inceleme ve kapsamlı bir literatür araştırması sonucunda oluşturulan hipotezleri test etmek amacıyla kullanılmaktadır. Betimleyici araştırmalarda örneklemin ana kütleyi temsil kabiliyeti yüksek olmaktadır (Nakip ve Yaraş, 2016, s. 29). Nicel araştırmalar ise, matematik tabanlı metotlarla analiz edilecek sayısal verilerin toplanarak belirli bir olayın açıklanmasını ifade etmektedir (Aliaga ve Gunderson, 2002).

\section{Araştırmanın Kapsam ve Kısıtları}

Araştırmanın kapsamı, yalnızca çevrimiçi alışveriş sitelerinden satın alım işlemlerini gerçekleştiren tüketicilerden oluşmaktadır. Araştırmada, zaman ve maliyet kısıtlamalarından dolayı 401 kullanılabilir anket formu analiz edilmiştir.

\section{Evren ve Örneklem}

Araştırmanın ana kütlesini, 18-60 yaş arası, çevrimiçi tüketiciler oluşturmaktadır. Katılımcıların internetten alışveriş yapıp yapmadıkları, anketler dağıtılmadan önce kişisel olarak sorulmuş olup, anket soruları yalnızca çevrimiçi tüketicilere dağıtılmıştır. Araştırma kapsamında, zaman ve maliyet kısıtlarından dolayı, uygun ve zaman alııı olmayan tesadüfi olmayan örnekleme yöntemlerinden kolayda örnekleme kullanılmıştır. Kolayda örnekleme, ana kütleden seçilen örneklemin, araştırmacılar tarafından belirlendiği bir yöntemdir. Ana kütleden verilerin toplanması kolayda örneklemede kolay, hızlı ve ekonomik bir şekilde gerçekleşmektedir (Malhotra ve Dash, 2016, s. 351). Çalışmada, veri toplamak için tasarlanan anket ilk olarak pilot çalışma kapsamında, 5 Ocak 2019 - 10 Ocak 2019 tarihleri arasında, 50 kişiye gönderilmiş, 37 kişi tarafından geri dönüş yapıımıştır. Pilot çalışma sonrasında ise güvenilirliği düşüren ifadeler anketten çıkarılmış, yeni anket formu, 26 Şubat 2019 - 10 Mart 2019 tarihleri arasında, 50 kişi haricindeki 500 kişiye daha gönderilmiş, 401 kişiden ise olumlu geri dönüş alınmıştır. 


\section{Araştırmanın Modeli ve Hipotezler}

Araştırma modelinin geliştirilmesi sürecinde belirlenen değişkenlerin bazılarının doğrudan ve pozitif yönlü ilişkiye sahip olduğu görülmektedir. Yapılan araştırmalar EAAP boyutlarından kaynak güvenilirliği, demografik benzerlik, bilgi ilgi düzeyi ve bilgi kapsamlılığının marka güvenini direkt ve pozitif olarak etkilediğini ortaya çıkarmaktadır. (Ruparelia vd., 2010, s. 256; Wu ve Wang, 2011, s. 448). Bilgi kullanışlıı̆ının ise, yine marka güvenine direkt etkisinin olduğu gözlemlenmiştir (Sheinin vd., 2011, s. 9, Erkan ve Evans, 2018, s. 621). Ek olarak literatürde marka güveni ile marka sadakatinin güçlü bir ilişki içerisinde olduğu ve EAAP ile marka güveni arasında pozitif bir ilişki bulunduğu görülmektedir (Sirdeshmukh vd., 2002, s. 15; Mabkhot vd., 2017, s. 77). Ancak yapılan çalışmalarda değişkenler arasında ayrı ayrı etki tespit edilse de EAAP'nin marka güveni aracılığı ile marka sadakatini etkilediğine dair bir çalışmaya rastlanılmamaktadır. Bu sebeple bu çalışmada EAAP ile marka sadakati arasındaki ilişkide marka güveninin aracı etkisi ölçülmeye çalışımaktadır. Literatürdeki bu boşluğa yönelik olarak geliştirilen araştırma modeli aşağıda görülmektedir.

Şekil 2. Araştırma Modeli

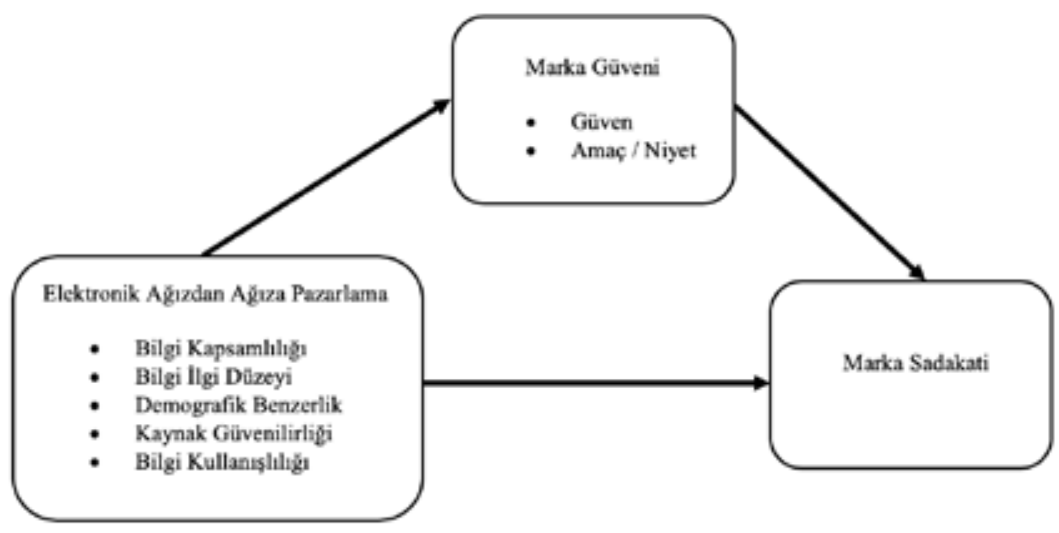

Araştırmada, bilgi benimseme modeli kapsamında incelenen EAAP'nin marka sadakati ile ilişkisinde marka güveninin aracı rolü incelenmiştir. Değişkenler arasında anlamlı ilişkilerin olup olmadığını analiz etmek amacıyla regresyon analizinden faydalanılmıştır. Araştırmada yer alan hipotezler doğrultusunda, değişkenlerin alt boyutları arasındaki ilișkileri ifade eden alt hipotezler incelenmiş ve hipotez sonuçlarına göre ana hipotezler yorumlanmıştır. Ayrıca, araştırma modelinin ana değişkenleri de regresyon analizine sokulmuş ve tüm hipotezlerin R2, anlamlılık ve B değerleri bulunmuştur. Çalışmanın devamında, aracı etkiyi incelemek amacıyla Baron ve Kenny aracılık analizi yapılmış olup kısmi ve tam aracııık etkilerinin anlamlı olup olmadığının belirlenmesi adına Sobel Testi uygulanmıştır. 
Araştırma modeli doğrultusunda geliştirilen hipotezler ise aşağıdaki gibidir:

\section{H1: EAAP ile marka güveni arasında anlamlı bir ilişki vardır.}

H1a: Bilgi kapsamlılığı ile güven arasında anlamlı bir ilişki vardır.

H1b: Bilgi kapsamlılığı ile amaç/niyet arasında anlamlı bir ilişki vardır.

H1c: Bilgi ilgi düzeyi ile güven arasında anlamlı bir ilişki vardır.

H1d: Bilgi ilgi düzeyi ile amaç/niyet arasında anlamlı bir ilişki vardır.

H1e: Demografik benzerlik ile güven arasında anlamlı bir ilişki vardır.

H1f: Demografik benzerlik ile amaç/niyet arasında anlamlı bir ilişki vardır.

H1g: Kaynak güvenilirliği ile güven arasında anlamlı bir ilişki vardır.

H1h: Kaynak güvenilirliği ile amaç/niyet arasında anlamlı bir ilişki vardir.

H1i: Bilgi kullanışlılığı ile güven arasında anlamlı bir ilişki vardır.

H1j: Bilgi kullanışıı̆ığı ile amaç/niyet arasında anlamlı bir ilişki vardır.

H2: Marka güveni ile marka sadakati arasında anlamlı bir ilişki vardır.

H2a: Güven ile marka sadakati arasında anlamlı bir ilişki vardır.

H2b: Amaç/niyet ile marka sadakati arasında anlamlı bir ilişki vardır.

\section{H3: EAAP ile marka sadakati arasında anlamlı bir ilişki vardır.}

H3a: Bilgi kapsamlılığı ile marka sadakati arasında anlamlı bir ilişki vardır.

H3b: Bilgi ilgi düzeyi ile marka sadakati arasında anlamlı bir ilişki vardir.

H3c: Demografik benzerlik ile marka sadakati arasında anlamlı bir ilişki vardır.

H3d: Kaynak güvenilirliği ile marka sadakati arasında anlamlı bir ilişki vardır.

H3e: Bilgi kullanışıı̆̆ı ile marka sadakati arasında anlamlı bir ilişki vardır.

H4: Marka güveni, EAAP'nin marka sadakati üzerindeki açıklayıcılığına aracı etkide bulunmaktadır.

H4a: Güven, bilgi kapsamlılığının marka sadakati üzerindeki açıklayıcılığına aracı etkide bulunmaktadır.

H4b: Niyet, bilgi kapsamlılığının marka sadakati üzerindeki açıklayıcılığına aracı etkide bulunmaktadır.

H4c: Güven, bilgi ilgi düzeyinin marka sadakati üzerindeki açıklayıcılığına aracı etkide bulunmaktadır.

H4d: Niyet, bilgi ilgi düzeyinin marka sadakati üzerindeki açıklayıcılığına aracı etkide bulunmaktadır.

H4e: Güven, demografik benzerliğin marka sadakati üzerindeki açık- 
layıcılığına aracı etkide bulunmaktadır.

H4f: Niyet, demografik benzerliğin marka sadakati üzerindeki açıklayıcılığına aracı etkide bulunmaktadır.

H4g: Güven, kaynak güvenilirliğinin marka sadakati üzerindeki açıklayıcılığına aracı etkide bulunmaktadır.

H4h: Niyet, kaynak güvenilirliğinin marka sadakati üzerindeki açıklayıcılığına aracı etkide bulunmaktadır.

H4i: Güven, bilgi kullanışııı̆ının marka sadakati üzerindeki açıklayıcılığına aracı etkide bulunmaktadır.

H4j: Niyet, bilgi kullanışlılığının marka sadakati üzerindeki açıklayıcılığına aracı etkide bulunmaktadır.

\section{Veri Toplama Aracı}

Çalışmada veriler, nicel araştırma yöntemleri kapsamında yer alan anket tekniği ile toplanmıştır. Çalışma için Google Forms'ta düzenlenen anket, katılımcılara internet ortamı aracılığıyla dağıtımıştır. Anket formunda yer alan ifadelerin açık, anlaşılır, cevaplayan kişileri sıkmayacak şekilde kısa ve yapısal olmasına dikkat edilmiştir. Çalışmanın amacı doğrultusunda oluşturulan anket, 34 ifadeyi içermektedir. Form, toplam olarak iki gruptan oluşmaktadır. Illk grupta kişilerin demografik özelliklerini belirleyici ifadeler yer almakta olup ikinci grupta ise EAAP'yi, marka güvenini ve marka sadakatini analiz etmeyi sağlayacak olan ifadeler yer almaktadır. Araştırmada, belirlenen değişkenlerin analiz edilebilmesi için tasarlanan anket formunda yararlanılan ölçek kaynakları Tablo 1'de gösterilmektedir.

Tablo 1. Araştırma Verilerine Ulaşmak Amacıyla Tasarlanan Anket Formunda Yararlanılan Ölçek Kaynakları

\begin{tabular}{|c|c|}
\hline $\begin{array}{l}\text { BILGI BENIMSEME MODELI KAPSAMINDA } \\
\text { EAAP DEĞISTENININ ALT BOYUTLARI }\end{array}$ & $\begin{array}{c}\text { OLLCEK } \\
\text { KAYNAKL.ARI }\end{array}$ \\
\hline Bilgi Ilgi Düzcyi & Citrin (2011) \\
\hline Bilgi Kapsamlılığı & Wixom ve Todd (2005) \\
\hline Demografik Benzerlik & Wu ve Shaffer (1997) \\
\hline Kaynak Gũvenilirlig̨i & Wu ve Shaffer (1997) \\
\hline Bilgi Kullanışlılığ & Bailey ve Pearson (1983) \\
\hline $\begin{array}{l}\text { MARKA GOVENI DEGIȘKENININ } \\
\text { ALT BOYUTLARI }\end{array}$ & $\begin{array}{c}\text { OLLCEK } \\
\text { KAYNAKL.ARI }\end{array}$ \\
\hline Gûven & Delgado-Ballester ve die (2003) \\
\hline Amac/Niyet & Delgado-Ballester ve dig (2003) \\
\hline MARKA SADAKATI DEĞİSKENI & $\begin{array}{c}\text { ÖLCEK } \\
\text { KAYNAKI_ARI }\end{array}$ \\
\hline Marka Sadakati & $\begin{array}{c}\text { Delgado-Ballester ve Manuera-Alemn } \\
(2005)\end{array}$ \\
\hline
\end{tabular}

Ankette tüketicilerin demografik özelliklerini belirlemeye yönelik olarak altı ifade yer almakta olup, ikinci gruptaki değişkenler için 28 ifade kullanılmıştır. Katılımcıların demografik özelliklerini belirlemeye yönelik olarak, cinsiyet, yaş, 
medeni durum, eğitim durumu, çalışma durumu ve aylık gelir ile ilgili altı adet kapalı uçlu soru bulunmaktadır. Íkinci gruptaki ifadeler ise 5'li Likert ölçeği ile ölçülmüș olup, ankete katılanların verecekleri yanıtlar "1=kesinlikle katılmıyorum, 2=katılmıyorum, 3=ne katılıyorum ne katımıyorum, 4=katııyorum, 5=kesinlikle katılıyorum" şeklindedir. Anket formunda yer alan ifadeler, katılımcılar tarafından anlaşıır olup olmadıklarının belirlenmesi amacıyla İngilizceden Türkçeye daha sonrasında Türkçeden Ingilizceye çevrilmiş ve ifadelerin anlaşılır olduğu tespit edilmiştir. Devamında, formda yer alan ifadelerin güvenilir olup olmadığını belirlemek amacıyla 37 kişi ile bir pilot çalışma yapılmıştır. Pilot çalışma sonrasında anlaşılamayan ve güvenilirliği düşüren ifade gözden geçirilmiş olup "Bilgi ilgi düzeyi" boyutunun ikinci ifadesinin (Çevrimiçi alışveriş sitelerindeki yorumlar özgündür.) yapılan analiz sonucunda güvenilirliği düşürdüğü sonucuna ulaşılmış ve bu ifade anketten çıkarılmıştır. Belirtilen düzenleme yapıldıktan sonra oluşan yeni anket, pilot çalışmada güvenilirlik analizine katılan 37 kişi haricinde, 401 kişi tarafından doldurulmuştur. Pilot araştırma sonrasında oluşturulan yeni anket formunda yer alan ölçeklere ayrı ayrı güvenirlik analizi uygulanmış ve bulunan Cronbach's Alfa değerleri Tablo 2'de gösterilmiştir. Tabloda yer alan değerlerden 0,900 üzerindekiler güvenilirliğin mükemmel olduğunu, 0,700 ile 0,800 arasındaki değerler ise güvenilirliğin yüksek olduğunu ifade etmektedir (Hinton vd., 2004, s. 357).

Tablo 2. Değişken ve Faktörlere Ait Cronbach's Alfa Değerleri

\begin{tabular}{|c|c|c|}
\hline Değişkenler & Faktörler & Cronbach's Alfa Değerleri \\
\hline \multirow{5}{*}{ EAAP } & Bilgi Kapsamlılığı & 0,878 \\
\hline & Bilgi Illgi Düzeyi & 0,808 \\
\hline & Demografik Benzerlik & 0,818 \\
\hline & Kaynak Güvenilirliği & 0,929 \\
\hline & Bilgi Kullanışlılığ1 & 0,897 \\
\hline \multirow{2}{*}{ Marka Gūveni } & Amaç/Niyet & 0,941 \\
\hline & Güven & 0,896 \\
\hline Marka Sadakati & Marka Sadakati & 0,825 \\
\hline
\end{tabular}

\section{Veri ve Bilgilerin Analizi}

Araştırma sonucunda elde edilen veriler, IBM SPSS (Statistical Package for Social Sciences) Statistics 20 for Mac programı kullanılarak analiz edilmiştir. Verilerin analizinde öncelikle frekans yüzde dağılımları yer almaktadır. Daha sonrasında verilere güvenilirlik ve faktör analizleri uygulanmıştır. Regresyon analizi ile değişkenler arasında anlamlı ilişkilerin olup olmadığı belirlenmiştir. Devamında aracı etkiyi incelemek amacıyla Baron ve Kenny aracılık analizi yapılmıştır. Son olarak araştırmada analizler ile belirlenen kısmi ve tam aracılık etkilerinin anlamlı olup olmadığının belirlenmesi adına Sobel Testi yapılmıştır. 


\section{Bulgular}

Tablo 3. Araştırma Örneklemine Ait Demografik Veriler

\begin{tabular}{|c|c|c|}
\hline Örnekleme Ait Demografik Veriler & $\begin{array}{l}\text { Frekans } \\
(n=401)\end{array}$ & $\begin{array}{c}\text { Yüzde } \\
(\%)\end{array}$ \\
\hline \multicolumn{3}{|l|}{ Cinsiyet } \\
\hline Kadın & 180 & 44,9 \\
\hline Erkek & 221 & 55,1 \\
\hline \multicolumn{3}{|l|}{ Yaş Grubu } \\
\hline 20'nin altı & 15 & 3,7 \\
\hline $20-29$ & 130 & 32,4 \\
\hline $30-39$ & 94 & 23,4 \\
\hline $40-49$ & 98 & 24,4 \\
\hline $50-59$ & 64 & 16 \\
\hline \multicolumn{3}{|l|}{ Medeni Durum } \\
\hline Bekar & 186 & 46,4 \\
\hline Evli & 215 & 53,6 \\
\hline \multicolumn{3}{|l|}{ Eğitim Düzeyi } \\
\hline İlkokul & 6 & 1,5 \\
\hline Ortaokul & 6 & 1,5 \\
\hline Lise & 72 & 18 \\
\hline Ön Lisans & 28 & 7 \\
\hline Lisans & 230 & 57,4 \\
\hline Yüksek Lisans & 54 & 13,5 \\
\hline Doktora & 5 & 1,2 \\
\hline \multicolumn{3}{|l|}{ Çalışma Durumu } \\
\hline Çalışmıyor & 45 & 11,2 \\
\hline Öğrenci & 52 & 13 \\
\hline Özel Sektör & 177 & 44,1 \\
\hline Kamu & 83 & 20,7 \\
\hline Diğer & 44 & 11 \\
\hline \multicolumn{3}{|l|}{ Aylık Gelir } \\
\hline $1.600 \mathrm{TL}$ ve altı & 48 & 12 \\
\hline $1.601-2.000 \mathrm{TL}$ & 25 & 6,2 \\
\hline $2.001-3.000 \mathrm{TL}$ & 59 & 14,7 \\
\hline $3.001-4.000 \mathrm{TL}$ & 72 & 18 \\
\hline 4.000 TL ve üzeri & 197 & 49,1 \\
\hline
\end{tabular}


Çalışmada keşfedici faktör analizi yapılmadan önce verilerin temel bileşenler analizine uygunluğunu saptamak amacıyla Kaiser-Meyer Olkin (KMO) örnekleme uygunluk ölçümü ve Barlett Sphericity (Küresellik) Testi yapılmıştır. EAAP ölçeğine yönelik yapılan faktör analizinde KMO değeri 0,907 ve açıklanan toplam varyans $\% 78,803$ olarak belirlenmiştir. Ancak faktör yük değerlerine bakıldığında, sosyal bilimlerde eşik değer olarak kabul edilen $0,45^{\prime}$ in altında olan 1 ifade tespit edilmiştir (Hinton vd., 2004, s. 341). Demografik benzerlik faktörü altındaki ifadelerden sonuncusu olan "Çevrimiçi alışveriş sitelerinde ürünü satın aldığım yoldan (internetten, mağazadan) satın alan kişilerin yaptığı yorumlara güvenirim." ifadesinin faktör yükü 0,30'dan düşük çıkmıştır. Bu ifade çıkarılarak, faktör analizi tekrar yapılmıştır. Analizin devamında EAAP değişkeninin KMO katsayısı 0,897 olduğundan veri setinin faktör analizi yapmak için "mükemmel" olduğu söylenilebilmektedir (Hinton vd., 2004, s. 347). Ayrıca yapılan faktör analizinde anlamlılık değeri p(sign.) $=0,000<0,05$ olduğundan (Hinton vd., 2004, s. 95), Bartlett's Testinin sonucunun da anlamlı olduğu görülmektedir. Bu durumda değişkenler arasında korelasyon mevcuttur ve veri seti faktör analizine uygundur yorumu yapılabilmektedir. Faktör analizine ait özet sonuçlar Tablo 4'te gösterilmektedir. Anket formunda yer alan "bu marka" ifadesi ile katılımcıların anketi doldurma süreçlerinde, kullanmış oldukları çevrimiçi alışveriş sitelerinden, en son satın almış oldukları ürünlerin markalarını düşünerek yanıt vermeleri istenmiştir.

Tablo 4. Araştırma Değişkenlerinin Faktör Grupları, Faktör Açıklayıcılıkları ve Faktör Yüklerine Yönelik Özet Tablo

\begin{tabular}{|c|c|c|c|}
\hline $\begin{array}{l}\text { Faktör } \\
\text { Grubu }\end{array}$ & $\begin{array}{l}\text { Faktörün } \\
\text { Açıklayıcılığı }\end{array}$ & İfadeler & $\begin{array}{l}\text { Faktör } \\
\text { Yükleri }\end{array}$ \\
\hline \multirow{4}{*}{$\begin{array}{c}\text { Bilgi } \\
\text { Kapsamlılığı }\end{array}$} & \multirow{4}{*}{$\% 21,60$} & $\begin{array}{l}\text { Çevrimiçi alışveriş sitelerindeki yorumlar ihtiyacım olan } \\
\text { yeterli bilgiye ulaşmamı sağlamaktadır. }\end{array}$ & 0,771 \\
\hline & & $\begin{array}{l}\text { Çevrimiçi alışveriş sitelerindeki yorumlar gerekli faydayı } \\
\text { sağlamaktadır. }\end{array}$ & 0,620 \\
\hline & & $\begin{array}{l}\text { Çevrimiçi alışveriş sitelerindeki yorum içerikleri intiyacım } \\
\text { olan bilgileri kapsamaktadır. }\end{array}$ & 0,813 \\
\hline & & Çevrimiçi alışveriş sitelerindeki yorumlar kapsamlıdır. & 0,672 \\
\hline \multirow{3}{*}{$\begin{array}{l}\text { Demografik } \\
\text { Benzerlik }\end{array}$} & \multirow{3}{*}{$\% 17,30$} & $\begin{array}{l}\text { Çevrimiçi alışveriş sitelerinde yaşıtlarım tarafından } \\
\text { yapılan yorumlara güvenirim. }\end{array}$ & 0,842 \\
\hline & & $\begin{array}{l}\text { Çevrimiçi alışveriş sitelerinde hemcinslerim tarafından } \\
\text { yapılan yorumlara güvenirim. }\end{array}$ & 0,779 \\
\hline & & $\begin{array}{l}\text { Çevrimiçi alışveriş sitelerinde benimle aynı tür ilgi alanına } \\
\text { sahip olan kişiler tarafından yapılan yorumlara güvenirim. }\end{array}$ & 0,519 \\
\hline \multirow{2}{*}{$\begin{array}{l}\text { Bilgi Alaka } \\
\text { Düzeyi }\end{array}$} & \multirow[t]{2}{*}{$\% 16,10$} & $\begin{array}{l}\text { Çevrimiçi alışveriş sitelerindeki yorumlar ürün ile } \\
\text { ilişkilidir. }\end{array}$ & 0,817 \\
\hline & & Çevrimiçi alışveriş sitelerindeki yorumlar ürün ile ilgilidir. & 0,801 \\
\hline \multirow{2}{*}{$\begin{array}{c}\text { Kaynak } \\
\text { Güvenilirliği }\end{array}$} & \multirow{2}{*}{$\% 13,10$} & $\begin{array}{l}\text { Çevrimiçi alışveriş sitelerine yorum yazan tüketicilerin } \\
\text { güvenilir olduğunu düşünürüm. }\end{array}$ & 0,875 \\
\hline & & $\begin{array}{l}\text { Çevrimiçi alışveriş sitelerine yorum yazan tüketicilerin } \\
\text { inanılır olduğunu düşünürüm. }\end{array}$ & 0,871 \\
\hline
\end{tabular}




\begin{tabular}{|c|c|c|c|}
\hline \multirow{3}{*}{$\begin{array}{c}\text { Bilgi } \\
\text { Kullanışlıı̆ı }\end{array}$} & \multirow{3}{*}{$\% 12,10$} & $\begin{array}{l}\text { Çevrimiçi alışveriş sitelerindeki yorumların önemli } \\
\text { olduğunu düşünürüm. }\end{array}$ & 0,850 \\
\hline & & $\begin{array}{l}\text { Çevrimiçi alışveriş sitelerindeki yorumların bilgilendirici } \\
\text { olduğunu düşünürüm. }\end{array}$ & 0,850 \\
\hline & & $\begin{array}{l}\text { Çevrimiçi alışveriş sitelerindeki yorumların faydalı } \\
\text { olduğunu düşünürüm. }\end{array}$ & 0,800 \\
\hline EAAP & $\% 80,19$ & KMO = 0,897 & \\
\hline \multirow{5}{*}{ Amaç/Niyet } & \multirow{5}{*}{$\% 42,68$} & $\begin{array}{l}\text { Bu marka endişe duyduğum konulara cevap verirken } \\
\text { samimi olacaktır. }\end{array}$ & 0,714 \\
\hline & & $\begin{array}{l}\text { Bu marka endişe duyduğum konulara cevap verirken } \\
\text { dürüst olacaktır. }\end{array}$ & 0,752 \\
\hline & & $\begin{array}{l}\text { Bu markaya, ürünle ilgili herhangi bir sorunu çözme } \\
\text { konusunda güvenebilirim. }\end{array}$ & 0,790 \\
\hline & & $\begin{array}{l}\text { Bu marka bir sorun olduğunda beni tatmin edecek her } \\
\text { türlü çabayı gösterecektir. }\end{array}$ & 0,985 \\
\hline & & $\begin{array}{l}\text { Bu marka ürünle ilgili yaşadığım herhangi bir sorunu } \\
\text { telafi edecektir. }\end{array}$ & 0,871 \\
\hline \multirow{4}{*}{ Güven } & \multirow{4}{*}{$\% 36,50$} & Bu marka beklentilerimi karşılamaktadır. & 0,882 \\
\hline & & Bu markaya güvenirim. & 0,782 \\
\hline & & Bu marka beni hiçbir zaman hayal kırıklığına uğratmaz. & 0,794 \\
\hline & & Bu marka beni memnun edeceğini garanti etmektedir. & 0,723 \\
\hline $\begin{array}{l}\text { Marka } \\
\text { Güveni }\end{array}$ & $\% 79,17$ & KMO = 0,922 & \\
\hline \multirow{4}{*}{$\begin{array}{l}\text { Marka } \\
\text { Sadakati }\end{array}$} & \multirow{4}{*}{$\% 65,67$} & Bu markaya sadık olduğumu düşünmekteyim. & 0,689 \\
\hline & & $\begin{array}{l}\text { Yalnızca beklenmedik/alışıımadık bir durumda, bu } \\
\text { markadan farklı bir markanın ürününü satın alııım. }\end{array}$ & 0,688 \\
\hline & & $\begin{array}{l}\text { Eğer bir mağazada bu markanın ürünü satılmıyorsa, } \\
\text { markanın ürününü başka bir mağazada aramaya giderim. }\end{array}$ & 0,744 \\
\hline & & $\begin{array}{l}\text { Farklı bir marka satışta olsa bile, bu markanın ürününü } \\
\text { satın almayı tercih ederim. }\end{array}$ & 0,824 \\
\hline $\begin{array}{l}\text { Marka } \\
\text { Sadakati }\end{array}$ & $\% 65,67$ & KMO = 0,897 & \\
\hline
\end{tabular}

Faktör analizi koşulları sağlandıktan sonra yapılan analizde ölçeğin beş boyutta açıklandığı tespit edilmiştir. Soru grupları, cevaplayıcıların \%80,19'u tarafından birbirleri ile ilişkili bulunarak beş temel boyutta görülmektedir. Bilgi kapsamlılığı boyutu toplam varyansın \%21,6'sını, demografik özellikler boyutu \%17,3'ünü, bilgi ilgi düzeyi \%16,1'ini, kaynak güvenilirliği boyutu \%13,1'ini, bilgi kullanışıı̆̆ı ise \%12,1'ini açıklamaktadır. Marka güveni değişkeni için KMO katsayısı ise 0,922 olduğundan veri setinin faktör analizi yapmak için "mükemmel" olduğu söylenebilmektedir (Malhotra ve Dash, 2016, s. 602). Ayrıca yapılan faktör analizinde anlamlılık değeri p(sign.)=0,000<0,05 olduğundan Bartlett's Testinin sonucunun da anlamlı olduğu görülmektedir. Bu durumda değişkenler 
arasında korelasyon mevcuttur ve veri seti faktör analizine uygundur yorumu yapılabilmektedir. Faktör analizi koşulları sağlandıktan sonra yapılan analizde ölçeğin iki boyutta açıklandığı tespit edilmiştir. Soru grupları, cevaplayıcıların \% 79,176'sı tarafından birbirleri ile ilişkili bulunarak iki temel boyutta görülmektedir. Niyet boyutu toplam varyansın \%42,68'ini, güven boyutu ise \%36,5'ini açıklamaktadır. Model son değişkeni olan marka sadakatinin KMO katsayısı 0,897 olduğundan veri setinin faktör analizi yapmak için "mükemmel" olduğu söylenilebilmektedir (Malhotra ve Dash, 2016, s. 602). Ayrıca yapılan faktör analizinde anlamlılık değeri p(sign.) $=0,000<0,05$ olduğundan Bartlett's Testinin sonucunun da anlamlı olduğu görülmektedir. Faktör analizi ile marka sadakati ölçeğinin tek boyuttan meydana geldiği tespit edilmiştir. Ölçek, toplam varyanstaki değişimin \%65,666'sını açıklamaktadır.

Tablo 5. EAAP'nin Marka Güveni Üzerindeki Etkilerine Yönelik Regresyon Analizi Sonuçları

\begin{tabular}{|c|c|c|c|c|c|}
\hline $\begin{array}{l}\text { Bağımsız } \\
\text { Değişken }\end{array}$ & $\begin{array}{l}\text { Bağımlı } \\
\text { Değişken }\end{array}$ & Hipotez & $\begin{array}{c}\text { Düzeltilmiş } \\
\mathbf{R}^{2}\end{array}$ & $\begin{array}{l}\text { Parametre } \\
\text { Tahmini B }\end{array}$ & $\underset{\text { Anlamlılık }}{\mathbf{P}}$ \\
\hline EAAP & Marka Güveni & $\mathrm{H}_{1}$ & 0,341 & 0,647 & 0,000 \\
\hline $\begin{array}{c}\text { Bilgi } \\
\text { Kapsamlılığı }\end{array}$ & Güven & $\mathrm{H}_{1 \mathrm{a}}$ & 0,277 & 0,510 & 0,000 \\
\hline $\begin{array}{c}\text { Bilgi } \\
\text { Kapsamlılığı }\end{array}$ & Niyet & $\mathrm{H}_{1 \mathrm{~b}}$ & 0,228 & 0,485 & 0,000 \\
\hline Bilgi İlgi Düzeyi & Güven & $\mathrm{H}_{1 \mathrm{c}}$ & 0,081 & 0,283 & 0,000 \\
\hline Bilgi İlgi Düzeyi & Niyet & $\mathrm{H}_{1 \mathrm{~d}}$ & 0,065 & 0,262 & 0,000 \\
\hline $\begin{array}{c}\text { Demografik } \\
\text { Benzerlik }\end{array}$ & Güven & $\mathrm{H}_{1 \mathrm{e}}$ & 0,250 & 0,435 & 0,000 \\
\hline $\begin{array}{c}\text { Demografik } \\
\text { Benzerlik }\end{array}$ & Niyet & $\mathrm{H}_{1 f}$ & 0,177 & 0,384 & 0,000 \\
\hline $\begin{array}{c}\text { Kaynak } \\
\text { Güvenilirliği }\end{array}$ & Güven & $\mathrm{H}_{1 \mathrm{~g}}$ & 0,174 & 0,359 & 0,000 \\
\hline $\begin{array}{c}\text { Kaynak } \\
\text { Güvenilirliği }\end{array}$ & Niyet & $\mathrm{H}_{1 \mathrm{~h}}$ & 0,133 & 0,331 & 0,000 \\
\hline Bilgi Kullanışlılığı & Güven & $\mathrm{H}_{1 \mathrm{i}}$ & 0,289 & 0,488 & 0,000 \\
\hline Bilgi Kullanışlılığı & Niyet & $\mathrm{H}_{1 \mathrm{j}}$ & 0,210 & 0,437 & 0,000 \\
\hline
\end{tabular}

Tablo 5'te yer alan değerler incelendiğinde, EAAP ile marka güveni arasındaki ilişkinin anlamlı olduğu $(p<0,05)$ sonucuna ulaşılmaktadır. Ek olarak, birbiriyle ilişkileri ayrı ayrı incelenen EAAP'nin alt boyutları ile marka güveninin alt boyutlarının da regresyon analizi sonuçlarının anlamlı olduğu ortaya çıkmaktadır. 
Tablo 6. Marka Güveninin Marka Sadakati Üzerindeki Etkilerine Yönelik Regresyon Analizi Sonuçları

\begin{tabular}{|c|c|c|c|c|c|}
\hline $\begin{array}{c}\text { Bağımsız } \\
\text { Değișken }\end{array}$ & $\begin{array}{c}\text { Bağımlı } \\
\text { Değişken }\end{array}$ & Hipotez & $\begin{array}{c}\text { Düzeltilmiş } \\
\mathbf{R}^{\mathbf{2}}\end{array}$ & $\begin{array}{c}\text { Parametre } \\
\text { Tahmini } \\
\mathbf{B}\end{array}$ & $\begin{array}{c}\mathbf{P} \\
\text { Anlamlıhk }\end{array}$ \\
\hline Marka Güveni & Marka Sadakati & $\mathrm{H}_{2}$ & 0,435 & 0,748 & 0,000 \\
\hline Güven & Marka Sadakati & $\mathrm{H}_{2 \mathrm{a}}$ & 0,368 & 0,668 & 0,000 \\
\hline Niyet & Marka Sadakati & $\mathrm{H}_{2 b}$ & 0,403 & 0,667 & 0,000 \\
\hline
\end{tabular}

Tablo 6'da yer alan değerler incelendiğinde, marka güveni ile marka sadakati arasındaki ilişkinin anlamlı olduğu $(p<0,05)$ sonucuna ulaşılmaktadır. Illaveten birbirleriyle ilişkileri ayrı ayrı incelenen marka güveni alt boyutları ile marka sadakatinin sonuçlarının anlamlı olduğu ortaya çıkmaktadır.

Tablo 7. EAAP'nin Marka Sadakati Üzerindeki Etkilerine Yönelik Regresyon Analizi Sonuçları

\begin{tabular}{|c|c|c|c|c|c|}
\hline $\begin{array}{l}\text { Bağımsız } \\
\text { Değişken }\end{array}$ & $\begin{array}{l}\text { Bağımlı } \\
\text { Değişken }\end{array}$ & Hipotez & $\begin{array}{c}\text { Düzeltilmiş } \\
\mathbf{R}^{2}\end{array}$ & $\begin{array}{l}\text { Parametre } \\
\text { Tahmini B }\end{array}$ & $\underset{\text { Anlamlılık }}{\mathbf{P}}$ \\
\hline EAAP & Marka Sadakati & $\mathrm{H}_{3}$ & 0,208 & 0,575 & 0,000 \\
\hline Bilgi Kapsamlılığı & Marka Sadakati & $\mathrm{H}_{3 \mathrm{a}}$ & 0,185 & 0,459 & 0,000 \\
\hline Bilgi İlgi Düzeyi & Marka Sadakati & $\mathrm{H}_{3 \mathrm{~b}}$ & 0,033 & 0,203 & 0,000 \\
\hline $\begin{array}{c}\text { Demografik } \\
\text { Benzerlik }\end{array}$ & Marka Sadakati & $\mathrm{H}_{3 \mathrm{c}}$ & 0,126 & 0,341 & 0,000 \\
\hline $\begin{array}{c}\text { Kaynak } \\
\text { Güvenilirliği }\end{array}$ & Marka Sadakati & $\mathrm{H}_{3 \mathrm{~d}}$ & 0,112 & 0,315 & 0,000 \\
\hline Bilgi Kullanışlılığı & Marka Sadakati & $\mathrm{H}_{3 \mathrm{e}}$ & 0,179 & 0,423 & 0,000 \\
\hline
\end{tabular}

Tablo 7'de yer alan değerlere göre, EAAP ile marka sadakati arasındaki ilişkinin anlamlı olduğu $(p<0,05)$ sonucuna ulaşımaktadır. Ek olarak birbirleriyle ilişkileri ayrı ayrı incelenen EAAP alt boyutları ile marka sadakatinin sonuçlarının anlamlı olduğu ortaya çıkmaktadır.

Çalışmada, EAAP ve marka sadakati ilişkisinde marka güveninin aracı rolünü incelemek amacıyla Baron ve Kenny'nin (1986) çalışmasından yararlanılarak hiyerarşik regresyon analizi uygulanmıştır. 
Şekil 3. Araştırmanın Aracılık Etki Modeli

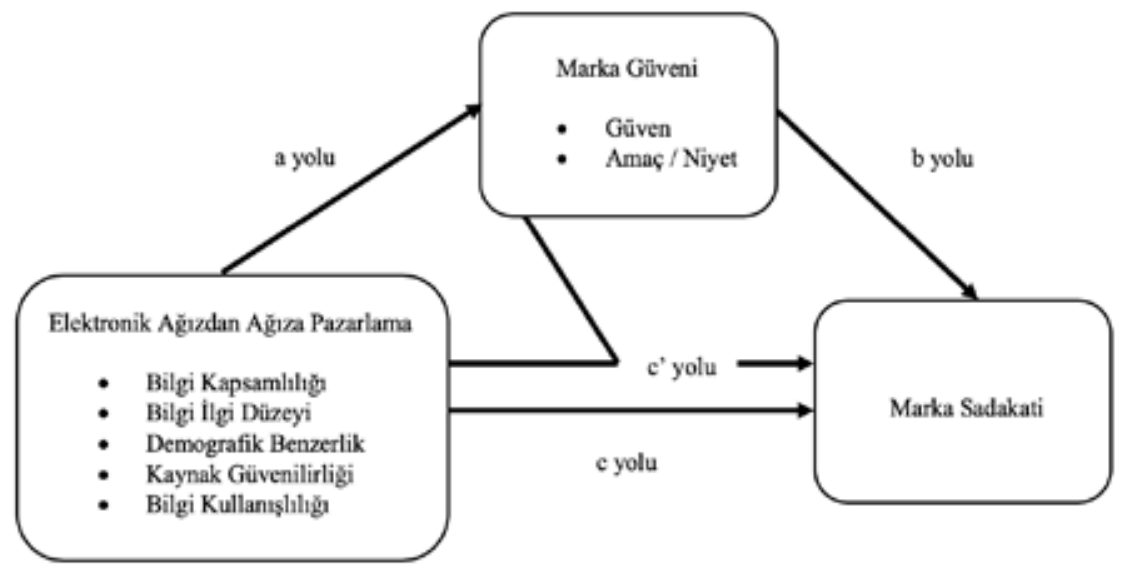

Baron ve Kenny (1986, s. 1174) aracılık analizine göre, Şekil 3'te gösterilen a, b ve c yollarında bağımsız değişkenlerin bağımlı değişkenler üzerinde anlamlı bir ilişkinin olması koşulu aranmaktadır. Yapılmış olan korelasyon analizlerinde belirtilen ilişkilerin var olduğu sonucuna ulaşılmıştır. Aracılık analizi için ise c' yolunun incelenmesi gerekmektedir.

Tablo 8. EAAP ile Marka Sadakati Arasında Marka Güveninin Aracı Etkisi Özet Tablosu

\begin{tabular}{|c|c|c|c|c|c|c|c|c|c|}
\hline \multirow{2}{*}{$\begin{array}{l}\text { Bağımsız } \\
\text { Değişken }\end{array}$} & \multirow{2}{*}{$\begin{array}{c}\text { Aracı } \\
\text { Değişken }\end{array}$} & \multirow{2}{*}{$\begin{array}{l}\text { Bağıml } \\
\text { Değişken }\end{array}$} & \multicolumn{4}{|c|}{ B Katsayıs! } & \multirow{2}{*}{$\begin{array}{c}\text { B } \\
\text { Farkı }\end{array}$} & \multirow{2}{*}{$\begin{array}{c}\text { Araci } \\
\text { Etki }\end{array}$} & \multirow{2}{*}{$\begin{array}{c}\text { Z Skor } \\
\text { Katsayıs! }\end{array}$} \\
\hline & & & a yolu & b yolu & c yolu & c' yolu & & & \\
\hline EAAP & $\begin{array}{l}\text { Marka } \\
\text { Güveni }\end{array}$ & $\begin{array}{c}\text { Marka } \\
\text { Sadakati }\end{array}$ & 0,647 & 0,748 & 0,575 & 0,138 &, 437 & Kısmi & 9, \\
\hline
\end{tabular}

EAAP ve marka güveni faktörlerinin marka sadakati üzerindeki açıklayıcılıkları, iki değişkenin birlikte regresyon analizine tabi tutularak incelendiğinde ( $c^{\prime}$ yolu) EAAP'nin marka sadakati ile olan ilişkisinin hala anlamlı olduğuna ulaşımış fakat B katsayısının 0,437 oranında azaldığı gözlemlenmiştir. B değerindeki azalma miktarının anlamlı olup olmadığının belirlenmesi için Sobel Testi'nden yararlanılarak Sobel Z skor katsayısı 1,96'dan büyük ve p anlamlılık değerinin ise 0,05'ten küçük olduğu sonucuna ulaşımıştır. Belirtilen değerler, B değerindeki değişimin anlamlı olduğunu ortaya çıkarmıştır (Sobel, 1982, s. 305). Yapılan analizlerden yola çıkarak, marka güveninin EAAP ve marka sadakati arasındaki ilişkide kısmi aracı etkiye sahip olduğu yorumu yapılmakta olup araştırmada kurulmuş olan $\mathrm{H} 4$ hipotezi kabul edilmiştir. 
Tablo 9. EAAP Alt Boyutları ile Marka Sadakati Arasında Güven Alt Boyutunun Aracı Etkisi Özet Tablosu

\begin{tabular}{|c|c|c|c|c|c|c|c|c|c|}
\hline \multirow{2}{*}{$\begin{array}{l}\text { Bağımsız } \\
\text { Değișken }\end{array}$} & \multirow{2}{*}{$\begin{array}{c}\text { Aracı } \\
\text { Deǧiş̧en }\end{array}$} & \multirow{2}{*}{$\begin{array}{c}\text { Bağımlı } \\
\text { Deği̧̧ken }\end{array}$} & \multicolumn{4}{|c|}{ B Katsayısı } & \multirow{2}{*}{$\begin{array}{c}\text { B } \\
\text { Farka }\end{array}$} & \multirow{2}{*}{$\begin{array}{c}\text { Arac1 } \\
\text { Etki }\end{array}$} & \multirow{2}{*}{$\begin{array}{c}\text { Z Skor } \\
\text { Katsayss }\end{array}$} \\
\hline & & & a yolu & b yolu & c yolu & $c^{\prime}$ yolu & & & \\
\hline $\begin{array}{c}\text { Bilgi } \\
\text { Kapsamlihğg }\end{array}$ & \multirow{5}{*}{ Gūven } & \multirow{5}{*}{$\begin{array}{c}\text { Marka } \\
\text { Sadakati }\end{array}$} & 0,510 & 0,668 & 0,459 & 0,164 & 0,295 & Kısmi & 8,378 \\
\hline $\begin{array}{c}\text { Bilgi flgi } \\
\text { Düzeyi }\end{array}$ & & & 0,283 & 0,668 & 0,203 & 0,015 & 0,188 & Tam & 5,557 \\
\hline $\begin{array}{l}\text { Demografik } \\
\text { Benzerlik }\end{array}$ & & & 0,435 & 0,668 & 0,341 & 0,068 & 0,273 & Tam & 8,467 \\
\hline $\begin{array}{c}\text { Kaynak } \\
\text { Güvenilirliği }\end{array}$ & & & 0,356 & 0,668 & 0,315 & 0,091 & 0,224 & Kısmi & 7,512 \\
\hline $\begin{array}{c}\text { Bilgi } \\
\text { Kullanışhlığ }\end{array}$ & & & 0,488 & 0,668 & 0,423 & 0,138 & 0,285 & Kısmi & 8,563 \\
\hline
\end{tabular}

EAAP'nin alt boyutları ile marka sadakati arasındaki ilişkide, marka güveninin alt boyutlarından biri olan güvenin aracı rolünün incelendiği analizin sonuçları Tablo 9'da yer almaktadır. Bilgi ilgi düzeyi ve demografik benzerlik alt boyutlarının güven alt boyutu ile birlikte analize dahil edilerek marka sadakati ile ilişkilerinin incelenmesi sonucunda, bilgi ilgi düzeyi ve demografik benzerliğin marka sadakati ile anlamlı bir ilişkisinin kalmadığı gözlemlenmektedir. Dolayısıyla güven, bilgi ilgi düzeyi ve demografik benzerlik boyutlarının marka sadakati ile ilişkisinde tam aracı etkiye sahiptir yorumu yapılmakta olup $\mathrm{H} 4 \mathrm{c}$ ve $\mathrm{H} 4 \mathrm{e}$ hipotezleri kabul edilmektedir. Bilgi kapsamlılığı, kaynak güvenilirliği ve bilgi kullanışııığı boyutları ise ayrı ayrı güven alt boyutu ile birlikte regresyon analizine dahil edildiğinde, marka sadakati ile olan ilişkilerinin hala anlamlı olduğu sonucuna ulaşılmakta fakat B katsayılarında azalma gözlemlenmektedir. B katsayılarındaki azalmaların anlamlı olup olmadıklarının belirlenmesi amacıyla Sobel testi yapılmıştır. Yapılan analizler neticesinde, bilgi kapsamlılığı, kaynak güvenilirliği ve bilgi kullanışlıığının marka sadakati ile ilişkisinde güven alt boyutunun kısmi aracı etkiye sahip olduğu sonucuna ulaşılmaktadır. Belirtilen sonuçlar neticesinde, $\mathrm{H} 4 \mathrm{a}, \mathrm{H} 4 \mathrm{~g}$, $\mathrm{H} 4 \mathrm{i}$ hipotezleri kabul edilmiştir.

Tablo 10. EAAP Alt Boyutları ile Marka Sadakati Arasında Niyetin Aracı Etkisi Özet Tablosu

\begin{tabular}{|c|c|c|c|c|c|c|c|c|c|}
\hline \multirow{2}{*}{$\begin{array}{l}\text { Bağımsız } \\
\text { Değişken }\end{array}$} & \multirow{2}{*}{$\begin{array}{c}\text { Arracı } \\
\text { Deő̆işken }\end{array}$} & \multirow{2}{*}{$\begin{array}{c}\text { Bağımli } \\
\text { Değlişken }\end{array}$} & \multicolumn{4}{|c|}{ B Katsayısı } & \multirow{2}{*}{$\begin{array}{c}\text { B } \\
\text { Farkı }\end{array}$} & \multirow{2}{*}{$\begin{array}{c}\text { Araci } \\
\text { Etki }\end{array}$} & \multirow{2}{*}{$\begin{array}{c}\text { Z Skor } \\
\text { Katsayısı }\end{array}$} \\
\hline & & & a yolu & b yolu & c yolu & $\mathrm{c}^{*}$ yolu & & & \\
\hline $\begin{array}{c}\text { Bilgi } \\
\text { Kapsamlilığ }\end{array}$ & \multirow{5}{*}{ Niyet } & \multirow{5}{*}{$\begin{array}{c}\text { Marka } \\
\text { Sadakati }\end{array}$} & 0,485 & 0,667 & 0,459 & 0,176 & 0,283 & Kısmi & 8,395 \\
\hline $\begin{array}{l}\text { Bilgi Ilgi } \\
\text { Düzeyi }\end{array}$ & & & 0,262 & 0,667 & 0,203 & 0,03 & 0,173 & Tam & 4,970 \\
\hline $\begin{array}{c}\text { Demografik } \\
\text { Benzerlik }\end{array}$ & & & 0,384 & 0,667 & 0,341 & 0,104 & 0,237 & Kismi & 7,796 \\
\hline $\begin{array}{c}\text { Kaynak } \\
\text { Güvenilirliği }\end{array}$ & & & 0,311 & 0,667 & 0,315 & 0,109 & 0,206 & Kismi & 6,920 \\
\hline $\begin{array}{c}\text { Bilgi } \\
\text { Kullanıșlılığı }\end{array}$ & & & 0,437 & 0,667 & 0,423 & 0,168 & 0,255 & Kismi & 8,123 \\
\hline
\end{tabular}


EAAP'nin alt boyutları ile marka sadakati arasındaki ilişkide, marka güveninin bir diğer alt boyutu olan niyetin aracı rolüne dair elde edilen bilgiler Tablo 10'da yer almaktadır. Bilgi ilgi düzeyi boyutunun niyet ile birlikte regresyon analizine dahil edilerek marka sadakati ile ilişkisinin incelendiği analiz aracılığıyla, bilgi ilgi düzeyinin marka sadakati ile anlamlı bir ilişkisinin kalmadığı sonucuna ulaşımakta olup niyetin bilgi ilgi düzeyi ile marka sadakati arasındaki ilişkide tam aracı etkiye sahip olduğu yorumu yapılmaktadır. Yapılan analizler sonucunda H4d hipotezi kabul edilmiştir. Bilgi kapsamlılığı, demografik benzerlik, kaynak güvenilirliği ve bilgi kullanışılığı boyutları ise niyet boyutu ile birlikte ayrı ayrı regresyon analizine dahil edildiğinde marka sadakati ile olan ilişkilerinin hala anlamlı olduğu sonucuna ulaşılmakta fakat B katsayılarında azalma gözlemlenmektedir. Sobel testi aracıllğıyla, B katsayılarındaki azalmaların anlamlı olduğu ve böylece niyetin belirtilen alt boyutlar ile marka sadakati arasındaki ilişkilerde kısmi aracı etkiye sahip olduğu yorumu yapılmaktadır. Yapılan analizler ışığında H4b, H4j, H4h ve H4j hipotezleri kabul edilmiştir.

Araştırmada belirlenen $\mathrm{H} 1, \mathrm{H} 2$ ve $\mathrm{H} 3$ ana hipotezleri ile alt hipotezlerinin, uygulanan analizler sonucunda elde edilen bulgular doğrultusunda kabul ya da ret durumları Tablo 11'de gösterilmektedir. 
Tablo 11. Hipotez Sonuçları Özet Tablosu

\begin{tabular}{|c|c|c|}
\hline $\begin{array}{l}\text { Hipotez } \\
\text { Numarası }\end{array}$ & Hipotez & Sonuç \\
\hline H1 & EAAP ile marka gūveni arasında anlamlı bir ilişki vardır. & KABUL \\
\hline Hla & Bilgi kapsamlılığı ile gūven arasında anlamlı bir ilişki vardır. & KABUL \\
\hline $\mathrm{HIb}$ & Bilgi kapsamlılığı ile amaç/niyet arasında anlamlı bir ilişki vardır. & KABUL \\
\hline Hle & Bilgi ilgi dūzeyi ile gūven arasında anlamlı bir ilişki vardır. & KABUL \\
\hline HId & Bilgi ilgi dūzeyi ile amaç/niyet arasında anlamlı bir ilişki vardır. & KABUL \\
\hline Hle & Demografik benzerlik ile güven arasında anlamlı bir ilişki vardır. & KABUL \\
\hline HIf & Demografik benzerlik ile amą̧/niyet arasında anlamlı bir ilişki vardır. & KABUL \\
\hline $\mathrm{Hlg}$ & Kaynak gūvenilirliği ile güven arasında anlamlı bir ilişki vardır. & KABUL \\
\hline Hih & Kaynak gûvenilirliği ile amą̧̧níyet arasında anlamlı bir ilişki vardır. & KABUL \\
\hline H1i & Bilgi kullanışlı̆ı̆ı ile güven arasında anlamlı bir ilişki vardır. & KABUL \\
\hline H1j & Bilgi kullanışılığı ile amą̧/niyet arasında anlamlı bir ilişki vardır. & KABUL \\
\hline $\mathbf{H 2}$ & Marka güveni ile marka sadakati arasında anlamlı bir ilişki vardır. & KABUL \\
\hline $\mathrm{H} 2 \mathrm{a}$ & Gūven ile marka sadakati arasında anlamlı bir ilişki vardır. & KABUL \\
\hline $\mathrm{H} 2 \mathrm{~b}$ & Amaç/niyet ile marka sadakati arasında anlamlı bir ilişki vardır. & KABUL \\
\hline $\mathbf{H 3}$ & EAAP ile marka sadakati arasında anlamlı bir ilişki vardır. & KABUL \\
\hline $\mathrm{H} 3 \mathrm{a}$ & Bilgi kapsamlılığı ile marka sadakati arasında anlamlı bir ilişki vardır. & KABUL \\
\hline $\mathrm{H} 3 \mathrm{~b}$ & Bilgi ilgi dūzeyi ile marka sadakati arasında anlamlı bir iliş̧ki vardır. & KABUL \\
\hline $\mathrm{H} 3 \mathrm{c}$ & Demografik benzerlik ile marka sadakati arasında anlamlı bir ilişki vardır. & KABUL \\
\hline H3d & Kaynak güvenilirliği ile marka sadakati arasında anlamlı bir ilişki vardır. & KABUL \\
\hline $\mathrm{H} 3 \mathrm{e}$ & Bilgi kullanışılığı ile marka sadakati arasında anlamlı bir ilişki vardır. & KABUL \\
\hline
\end{tabular}

Aracılık hipotezlerinin özet sonuçları ise Tablo 12'de gösterilmektedir. 
Tablo 12. Aracılık Hipotez Sonuçları Özet Tablosu

\begin{tabular}{|c|c|c|}
\hline $\begin{array}{c}\text { Hipotez } \\
\text { Numarası }\end{array}$ & Hipotez & Sonuç \\
\hline H4 & $\begin{array}{l}\text { Marka gūveni, EAAP'nin marka sadakati ũzerindeki açıklayıcılığna aracı } \\
\text { etkide bulunmaktadır. }\end{array}$ & $\begin{array}{l}\text { KABUL } \\
\text { (Kısmi } \\
\text { Aracı) }\end{array}$ \\
\hline $\mathrm{H} 4 \mathrm{a}$ & $\begin{array}{l}\text { Güven, bilgi kapsamlılığının marka sadakati ûzerindeki açıklayıcıı̆̆ına aracı } \\
\text { etkide bulunmaktadır. }\end{array}$ & $\begin{array}{l}\text { KABUL } \\
\text { (Kismi } \\
\text { Aract) }\end{array}$ \\
\hline $\mathrm{H} 4 \mathrm{~b}$ & $\begin{array}{l}\text { Amaç, bilgi kapsamlılığını marka sadakati ūzerindeki açıklayıcılığına aracı } \\
\text { etkide bulunmaktadır. }\end{array}$ & $\begin{array}{l}\text { KABUL } \\
\text { (Kismi } \\
\text { Araci) } \\
\end{array}$ \\
\hline $\mathrm{H} 4 \mathrm{c}$ & $\begin{array}{l}\text { Gūven, Bilgi ilgi düzeyinin marka sadakati üzerindeki açıklayıcılığına aracı } \\
\text { etkide bulunmaktadır. }\end{array}$ & $\underset{\text { (Tam Araci) }}{\text { KABUL }}$ \\
\hline $\mathrm{H} 4 \mathrm{~d}$ & $\begin{array}{l}\text { Amaç, Bilgi ilgi dūzeyinin marka sadakati üzerindeki açıklayıcılığna aracı } \\
\text { etkide bulunmaktadr. }\end{array}$ & $\begin{array}{c}\text { KABUL } \\
\text { (Tam Araci) }\end{array}$ \\
\hline $\mathrm{H} 4 \mathrm{e}$ & $\begin{array}{l}\text { Güven, demografik benzerliğin marka sadakati üzerindeki açıklayıchığına aracı } \\
\text { etkide bulunmaktadır. }\end{array}$ & $\underset{\text { (Tam Araci) }}{\mathrm{KABUL}}$ \\
\hline $\mathrm{H} 4 \mathrm{f}$ & $\begin{array}{l}\text { Amaç, demografik benzerliğin marka sadakati ũzerindeki açıklayıeılı̆gına araeı } \\
\text { etkide bulunmaktadır. }\end{array}$ & $\begin{array}{c}\text { KABUL } \\
\text { (Kısmi } \\
\text { Aracı) } \\
\end{array}$ \\
\hline $\mathrm{H} 4 \mathrm{~g}$ & $\begin{array}{l}\text { Gūven, kaynak gūvenilirliğinin marka sadakati ūzerindeki açıklayıcıh̆̋̆ına aracı } \\
\text { etkide bulunmaktadır. }\end{array}$ & $\begin{array}{l}\text { KABUL } \\
\text { (Kısmi } \\
\text { Araci) } \\
\end{array}$ \\
\hline H4h & $\begin{array}{l}\text { Amaç, kaynak gūvenilirliğinin marka sadakati ũzerindeki açıklayıcılığına aracı } \\
\text { etkide bulunmaktadır. }\end{array}$ & $\begin{array}{l}\text { KABUL } \\
\text { (K1smi } \\
\text { Araci) } \\
\end{array}$ \\
\hline $\mathrm{H} 4 \mathrm{i}$ & $\begin{array}{l}\text { Güven, bilgi kullanış̧lılı̆ğın marka sadakati üzerindeki açıklayıcılığma aracı } \\
\text { etkide bulunmaktadır. }\end{array}$ & $\begin{array}{l}\text { KABUL } \\
\text { (Kısmi } \\
\text { Araci) } \\
\end{array}$ \\
\hline $\mathrm{H} 4 \mathrm{j}$ & $\begin{array}{l}\text { Amaç, bilgi kullanışhlığının marka sadakati üzerindeki açıklayıcılığına aracı } \\
\text { etkide bulunmaktadır. }\end{array}$ & $\begin{array}{l}\text { KABUL } \\
\text { (Kısmi } \\
\text { Aracı) } \\
\end{array}$ \\
\hline
\end{tabular}

Yapılan analizler sonucunda bulunan aracı etkilerden tam aracı etkide, bağımsız değişken ile bağımlı değişken arasında yer alan aracı değişken haricinde modelde başka bir aracının analiz edilmesine gerek olmamaktadır. Tam aracı değişken, bağımsız değişken ile bağımlı değişken arasındaki ilişkiyi tam anlamıyla açıklamaktadır (Rucker vd., 2011). Kısmi aracı değişken ise bağımsız değişken ile bağımlı değişken arasındaki ilişkinin bir kısmını açıklamaktadır. Bir başka deyiş ile bağımsız değişkenin bağımlı değişkeni etkilediği modelde, kısmi aracı değişken haricinde, araştırılabilecek farklı değişkenlerin varlığı ortaya çıkmaktadır (Preacher ve Kelley, 2011, s. 96).

\section{Sonuç ve Öneriler}

Günümüzde, teknolojinin hızlı bir şekilde gelişim göstermesiyle birlikte birçok alan dijitalleşmenin etkisi altına girmeye başlamıştır. Kişilerin karşılıklı olarak gerçekleştirmiş oldukları iletişim, zamanla elektronik ortama taşınmış olup 
kişilerin birbirleriyle herhangi bir marka, ürün ve hizmet hakkında bilgi alışverişinde bulunması, geleneksel ağızdan ağıza pazarlamayı farklı bir boyuta taşıyarak EAAP kavramını oluşturmuştur.

Kişiler internet aracılığıyla birçok sanal platformda birbirleriyle iletişim kurabilmekte ve ürün, marka ve hizmetler hakkında deneyimlerini, bilgileri ile değerlendirmelerini diğer tüketiciler ile paylaşabilmektedir. Çalışmada EAAP, çevimiçi alışveriş sitelerindeki tüketici yorumları kapsamında değerlendirilmiştir. Bu kapsamda tüketicilerin çevrimiçi alışveriş sitelerinde satılan markalar ve bu markaların ürünleri hakkında yazılmış olan farklı tüketici yorumlarını ne derecede benimsedikleri ve kendilerine ulaşan bu bilgilerin marka sadakatlerini etkileyip etkilemediği, marka güveninin aracı rolüyle analiz edilmiştir. Araştırmada, belirtilen unsurların, hakkında yorum yapılan ürünlerin markalarına olan sadakati etkileyici birer kavram olup olmadıklarının belirlenmesi esas alınmıştır.

Kişilerin EAAP'de, diğer tüketiciler tarafından paylaşılan bilgiler aracııı̆ıyla, hakkında yorum yapılan markaya yönelik güven duygusu beslemesi söz konusu olmaktadır. Tüketicilerin herhangi bir mağaza çalışanından ziyade, kendisiyle benzer konumda olan farklı bir tüketicinin yapmış olduğu yorumu dikkate alması ve kendi davranışlarını şekillendirmede bu yorumları değerlendirmesi daha olasıdır. Tüketicilerin değerlendirmiş oldukları bilgilerin özellikleri aracılığıyla markaya karşı güven duyması da markaya karşı besleyecekleri sadakati etkilemektedir. Güven duygusu ise tüketicilerin tekrar aynı markanın ürününü satın almalarını sağlamaktadır.

Tüketicilerin satın alma kararlarını vermeden önce, karşılaşabilecekleri riskleri en düşük seviyeye indirmek istemeleri ve günümüzde birçok kişinin kolay bir şekilde internete erişebiliyor olması, tüketici yorumlarının önem derecesini ortaya çıkarmaktadır. Dolayısıyla yorumların özelliklerinin, marka güveni ve marka sadakati yaratmada önemli faktörler oldukları belirlenmektedir.

Yapılan araştırmada tüketicilerin ürünler hakkında yapmış oldukları yorumların ayrıntılı olmasının, araştııılan ürün/marka ile ilgililiğinin, tüketicilerin yapacağı değerlendirmelerde istenen amacı sağlamasının, yorum paylaşan kişilerin güvenilirliğinin ve yorumu okuyan tüketiciyle aralarında herhangi bir demografik benzerlik olup olmamasının tüketicilerin, hakkında yorum yapılan markaya olan güvenlerini ve dolayısıyla marka sadakatlerini etkilediği sonucuna ulaşıımıştır. EAAP'nin bilgi benimseme modeline göre incelenen alt boyutlarından bilgi kapsamlılı̆ın, diğer boyutlara kıyasla marka sadakatini ve marka güvenini daha fazla etkilediği ortaya çıkmıştır. Kullanıcılar tarafından paylaşılan yorumların ayrıntılı içeriğe sahip olması, diğer tüketicilerin marka tutumlarını belirlemede büyük öneme sahiptir.

Araştırma kapsamında, işletmelerin çevrimiçi alışveriş sitelerinde yer alan tüketici yorumlarından kendi marka/ürünleri hakkındakilere önem vermeleri gerektiği düşünülmektedir. Illaveten organizasyonlar, yapılan yorumların içeriklerine göre, kendi ürünlerinde devam ettirecekleri veya geliştirebilecekleri özelliklerin neler olabileceği konusunda fikir sahibi olabilmektedirler. Böylece belirli değişiklikler ve 
iyileştirmeler sayesinde farklı tüketicilerin kendi marka ve ürünleri hakkında daha etkileyici yorumlar yapabilmelerine imkân sağlayarak markalarına duyulan güven ve sadakati artırabilecekleri sonucuna ulaşılmaktadır.

Yapılan çalışmanın literatürdeki araştırmalardan farklılaşan özelliği, EAAP'nin pazarlamanın bilgi benimseme modelinde, en yüksek etkiye sahip olan değişkenler ile ele alınmasıdır. Aynı zamanda araştırma yalnızca çevrimiçi ortamdaki tüketicilere odaklanmış olup, EAAP'nin araçlarından biri olan tüketici yorumları kapsamında değerlendirilmiştir. Çalışmada çevrimiç̧i tüketici yorumlarının tüketiciler tarafından benimsenme kriterlerinin, marka güveni aracılığıyla marka sadakatini etkileyip etkilemediği araştırılarak daha önce literatürde incelenmemiş olan bir model oluşturulmuştur. Bu çalışmanın bir diğer özgün yönü ise EAAP'nin tüketici sadakati üzerindeki etkisinin marka güveni aracılığı ile gerçekleşip gerçekleşmediğinin araştııımasıdır. Araştırma, bilgi kapsamlılı̆ının diğer boyutlara kıyasla marka güvenini ve marka sadakatini etkileme konusunda daha yüksek etkiye sahip olması sonucuyla, literatürdeki diğer çalışmalardan farklılaşmaktadır. Ayrıca marka güveninin, EAAP bilgi benimseme modeline göre belirlenen alt boyutlarının marka sadakati ile ilişkisinde aracı görev yaptığı sonucuna ulaşılarak, literatüre yeni bir sonuç eklenmiştir. Marka güveni ile marka sadakati arasında da anlamlı bir ilişkinin olması, literatürde bu konu hakkında yapılan çalışmalarla aynı sonuca ulaşıldığını göstermektedir.

Gelecekte yapılacak olan çalışmalarda, araştırmanın örneklemi daha fazla özelleştirilebilir. Marka güveninin aracı etkisinin incelenmesi ve etkinin kısmi olduğu sonucuna ulaşılmasından, araclık etkisine sahip olabilecek farklı değişkenler model oluşturmada kullanılabilir. EAAP'nin, tüketici alışveriş sitelerindeki yorumlar açısından incelenmesine ek olarak ileride yapılacak olan çalışmalarda, sosyal medya, bloglar, mikrobloglar gibi sanal ortamlardaki tüketici yorumlarının marka güveni ve marka sadakatine etkileri incelenebilir. Ek olarak tüketici yorumlarının, spesifik olarak çevrimiçi alışveriş sitelerine karşı güveni ve sadakati nasıl etkilediği ile ilgili konular da ileride yapılacak olan çalışmaların ana fikrini oluşturabilir. 


\section{Kaynakça}

Aksoy, L., Buoye, A., Aksoy, P., Larivière, B., \& Keiningham, T. L. (2013). A cross-national investigation of the satisfaction and loyalty linkage for mobile telecommunications services across eight countries. Journal of Interactive Marketing, 27(1), 74-82.

Aliaga, M. and Gunderson, B. (2002). Interactive Statistics. [Thousand Oaks]: Sage Publications.

AMA-American Marketing Association. (1960). Marketing definitions: A glossary of marketing terms. AMA, Chicago, IL.

Andaleeb, S. S. (1992). The trust concept: research issues for channels of distribution. Research in marketing, 11(1), 1-34.

Arndt, J. (1967). Role of product-related conversations in the diffusion of a new product. Journal of marketing Research, 4(3), 291-295.

Bailey, J. E., \& Pearson, S. W. (1983). Development of a tool for measuring and analyzing computer user satisfaction. Management science, 29(5), 530-545.

Baron, R. M., \& Kenny, D. A. (1986). The moderator-mediator variable distinction in social psychological research: Conceptual, strategic, and statistical considerations. Journal of personality and social psychology, 51(6), 1173.

Bhandari, M., \& Rodgers, S. (2018). What does the brand say? Effects of brand feedback to negative eWOM on brand trust and purchase intentions. International Journal of Advertising, 37(1), 125-141.

Blazevic, V., Hammedi, W., Garnefeld, I., Rust, R. T., Keiningham, T., Andreassen, T. W., ... \& Carl, W. (2013). Beyond traditional word-of-mouth: an expanded model of customer-driven influence. Journal of Service Management, 24(3), 294313.

BrightLocal, (2018). Local Customer Review Survey. https://www.brightlocal. com/learn/local-consumer-review-survey/\#local-business- review-habits.

Brody, R. P., \& Cunningham, S. M. (1968). Personality variables and the consumer decision process. Journal of Marketing Research, 5(1), 50-57.

Business Dictionary (2010). Brand Definition. Erişim, 30 Mayıs 2020, http://www. businessdictionary.com/definition/brand.html

Chaiken, S. (1980). Heuristic versus systematic information processing and the use of source versus message cues in persuasion. Journal of personality and social psychology, 39(5), 752-766.

Chaudhuri, A., \& Holbrook, M. B. (2001). The chain of effects from brand trust and brand affect to brand performance: the role of brand loyalty. Journal of marketing, 65(2), 81-93. 
Chen, Y., \& Xie, J. (2008). Online consumer review: Word-of-mouth as a new element of marketing communication mix. Management science, 54(3), 477-491.

Cheung, C. M., Lee, M. K., \& Rabjohn, N. (2008). The impact of electronic wordof-mouth: The adoption of online opinions in online customer communities. Internet research, 18(3), 229-247.

Chu, S. C., Lien, C. H., \& Cao, Y. (2019). Electronic word-of-mouth (eWOM) on WeChat: examining the influence of sense of belonging, need for self-enhancement, and consumer engagement on Chinese travellers' eWOM. International Journal of Advertising, 38(1), 26-49.

Citrin, A.V. (2001). Information quality perceptions: the role of communication media characteristics. Information and Learning, Vol. 17, 1-143.

Clare, C. J., Wright, G., Sandiford, P., \& Caceres, A. P. (2018). Why should I believe this? Deciphering the qualities of a credible online customer review. Journal of Marketing Communications, 24(8), 823-842.

Copeland, M. T. (1923). Relation of consumers' buying habits to marketing methods. Harvard business review, 1(3), 282-289.

Coursaris, C.K., Van Osch, W. (Temmuz 2016). Exploring the effects of source credibility on information adoption on YouTube. Proceedings of the International Conference on $\mathrm{HCl}$ in Business, Government and Organizations içinde, Springer, Cham, 16-25.

Daugherty, T., \& Hoffman, E. (2014). eWOM and the importance of capturing consumer attention within social media. Journal of Marketing Communications, 20(1-2), 82-102.

Day, G.S. (1969). A two-dimensional concept to brand loyalty. Journal of Advertising Research, Vol. 9 No. 3, 29-35.

Delgado-Ballester, E., \& Luis Munuera-Alemán, J. (2001). Brand trust in the context of consumer loyalty. European Journal of marketing, 35(11/12), 1238-1258.

Delgado-Ballester, E., Munuera-Aleman, J. L., \& Yague-Guillen, M. J. (2003). Development and validation of a brand trust scale. International Journal of Market Research, 45(1), 35-54.

Delgado Ballester, E., \& Munuera Alemán, J. L. (2005). Does brand trust matter to brand equity?. Journal of product \& brand management.

Doll, W.J. and Torkzadeh, G. (1988). The Measurement of End-User Computing Satisfaction, MIS Quarterly, 12 (2), 259-274.

Doney, P. M., \& Cannon, J. P. (1997). An examination of the nature of trust in buyer-seller relationships. Journal of marketing, 61(2), 35-51.

Elseidi, R. I., \& El-Baz, D. (2016). Electronic word of mouth effects on consumers' brand attitudes, brand image and purchase intention: an empirical study in 
Egypt. The Business \& Management Review, 7(5), 268.

Erkan, I., \& Evans, C. (2018). Social media or shopping websites? The influence of eWOM on consumers' online purchase intentions. Journal of Marketing Communications, 24(6), 617-632.

Farley, J. U. (1963). Testing a theory of brand loyalty. Proceedings of the American Marketing Association, December, 298-306.

Ferris-Costa, K. (2011). eWOM via mavens, buzz agents, and followers. University of Rhode Island.

Filieri, R., \& McLeay, F. (2014). E-WOM and accommodation: An analysis of the factors that influence travelers' adoption of information from online reviews. Journal of Travel Research, 53(1), 44-57.

Frank, R. E., Massy, W. F., \& Morrison, D. G. (1965). Bias in multiple discriminant analysis. Journal of Marketing Research, 2(3), 250-258.

Gass, R. H., \& Seiter, J. S. (2015). Persuasion: Social Influence and Compliance Gaining. Routledge.

Gkoumas, A. (2019). Electronic word-of-mouth as a Branding Tool for Sunset Restaurants. Global Journal of Management And Business Research, 1-13.

Hayes, B. E. (2008). The true test of loyalty. Quality Progress, 41(6), 20.

Herold K., Tarkiainen A. \& Sundqvist S. (2016). How the source of word-of-mouth influences information processing in the formation of brand attitudes, Journal of Marketing for Higher Education, 26:1, 64-85,

Hinton, P. R., McMurray, I., \& Brownlow, C. (2004). SPSS explained. Routledge. Huang, M. H., \& Yu, S. (1999). Are consumers inherently or situationally brand loyal?-A set intercorrelation account for conscious brand loyalty and nonconscious inertia. Psychology \& Marketing, 16(6), 523-544.

Huang, M., Cai, F., Tsang, A.S.L. \& Zhou, N. (2011). Making your online voice loud: the critical role of WOM information. European Journal of Marketing. 45(7/8). 1277- 1297.

Hussain, S., Ahmed, W., Jafar, R. M. S., Rabnawaz, A., \& Jianzhou, Y. (2017). eWOM source credibility, perceived risk and food product customer's information adoption. Computers in Human Behavior, 66, 96-102.

IdeaSoft (2019). 2019 KOBi E-ticaret Raporu. Erişim 20 Mayıs 2020, https://webrazzi.com/2020/03/25/kobi-e-ticaret-ideasoft/

Ismagilova, E., Slade, E., Rana, N. P., \& Dwivedi, Y. K. (2020). The effect of characteristics of source credibility on consumer behaviour: A meta-analysis. Journal of Retailing and Consumer Services, 53. 1-9.

Jacoby, J., \& Kyner, D. B. (1973). Brand loyalty vs. repeat purchasing behavi- 
or. Journal of Marketing research, 10(1), 1-9.

Jalilvand, M. R., \& Samiei, N. (2012). The impact of electronic word of mouth on a tourism destination choice: Testing the theory of planned behavior (TPB). Internet Research: Electronic Networking Applications and Policy, 22(5), 591-612.

Kantar (2019). Most Valuable Global Brands Report 2019. Erişim 20 Mayıs 2020, http://online.pubhtm/5.com/bydd/ksdy/

Kotler, P., \& Keller, K. L. (2009). Marketing management (13th end). New Jersey.

Kreis, H., \& Gottschalk, S. A. (2015). Relating eWOM Motives to eWOM Channel Choice-Why Do We Post Where We Do?. Schmalenbach Business Review, 67(4), 406-429.

Krishnamurthy, A., \& Kumar, S. R. (2018). Electronic word-of-mouth and the brand image: Exploring the moderating role of involvement through a consumer expectations lens. Journal of Retailing and Consumer Services, 43, 149-156.

Kudeshia, C., \& Kumar, A. (2017). Social eWOM: does it affect the brand attitude and purchase intention of brands?. Management Research Review, 40(3), 310-330.

Lake, C. (2013). 10 Customer Experience Soundbites from Jeff Bezos. Erişim 20 Mayıs 2020 https://econsultancy.com/10-customer-experience-soundbites-from-jeff-bezos/.

Li, X., \& Wu, L. (2018). Herding and social media word-of-mouth: Evidence from Groupon. Forthcoming at MISQ.

Liang, L. J., Choi, H. C., \& Joppe, M. (2018). Understanding repurchase intention of Airbnb consumers: perceived authenticity, electronic word-of-mouth, and price sensitivity. Journal of Travel \& Tourism Marketing, 35(1), 73-89.

Litvin, S. W., Goldsmith, R. E., \& Pan, B. (2008). Electronic word-of-mouth in hospitality and tourism management. Tourism management, 29(3), 458-468.

Liu, H., Jayawardhena, C., Dibb, S., \& Ranaweera, C. (2019). Examining the trade-off between compensation and promptness in eWOM-triggered service recovery: A restorative justice perspective. Tourism Management, 75, 381-392.

Lovett, M. J., Peres, R., \& Shachar, R. (2013). On brands and word of mouth. Journal of marketing research, 50(4), 427-444.

Mabkhot, H. A., Shaari, H., \& Salleh, S. M. (2017). The influence of brand image and brand personality on brand loyalty, mediating by brand trust: An empirical study. Jurnal Pengurusan (UKM Journal of Management), 50.

Malhotra, N. K., \& Dash, S. (2016). Marketing research: An applied orientation. Pearson.

Mayer, R. C., Davis, J. H., \& Schoorman, F. D. (1995). An Integrative Model Of Organizational Trust. Academy of Management Review, 20(3), 709-734. 
Morgan, R. M., \& Hunt, S. D. (1994). The commitment-trust theory of relationship marketing. Journal of marketing, 58(3), 20-38.

Nakip, M., \& Yaraş, E. (2016). SPSS uygulamalı pazarlama araştırmalarına giriş. Ankara: Seçkin Yayıncılık.

Oliver, Richard L. (1999). Whence Consumer Loyalty?, Journal of Marketing, 63 (Special Issue), 33-44.

Petty, R. E., \& Cacioppo, J. T. (1986). The elaboration likelihood model of persuasion. Communication and persuasion içinde Springer, New York, 1-24.

Pitta, D. A., \& Fowler, D. (2005). Internet community forums: an untapped resource for consumer marketers. Journal of Consumer Marketing, 22(5), 265-274.

Ransbotham, S., Lurie, N. H., \& Liu, H. (2019). Creation and Consumption of Mobile Word of Mouth: How Are Mobile Reviews Different?. Marketing Science, 38(5), 773-792.

Rempel, J.K., Holmes, J.G. and Zanna, M.P. (1985), Trust in close relationships. Journal of Personality and Social Psychology, Vol. 49 No. 1, 95-112.

Review42, (2019) 33+ Eye-Opening Word of Mouth Marketing Statistics. Erişim 20 Mayıs 2020, https://review42.com/word-of-mouth-marketing-statistics/

Riffai, M. M. M. A., Grant, K., \& Edgar, D. (2012). Big TAM in Oman: Exploring the promise of on-line banking, its adoption by customers and the challenges of banking in Oman. International journal of information management, 32(3), 239250.

Ruparelia, N., White, L., \& Hughes, K. (2010). Drivers of brand trust in internet retailing. Journal of Product \& Brand Management, 19(4), 250-260.

Sheinin, D. A., Varki, S., \& Ashley, C. (2011). The differential effect of ad novelty and message usefulness on brand judgments. Journal of Advertising, 40(3), 5-18.

Sirdeshmukh, D., Singh, J., \& Sabol, B. (2002). Consumer trust, value, and loyalty in relational exchanges. Journal of marketing, 66(1), 15-37.

Sobel, Michael E., (1982), "Asymptotic Confidence Intervals for Indirect Effects in Structural Equations Models", In S. Leinhart (Ed.), Sociological methodology, Vol.13, 290-312.

Suri, R., \& Monroe, K. B. (2003). The effects of time constraints on consumers' judgments of prices and products. Journal of consumer research, 30(1), 92-104.

Sussman, S. W., \& Siegal, W. S. (2003). Informational influence in organizations: An integrated approach to knowledge adoption. Information systems research, 14(1), 47-65.

TUBISAD, (2019). E-ticaretin Gelişimi, Sınırların Aşılması ve Yeni Normlar 2019 Raporu. Erişim 20 Mayıs 2020, http://www.tubisad.org.tr/tr/images/pdf/dd-tusiad-eticaret-raporu-2019.pdf 
Tucker, W. T. (1964) The Development of Brand Loyalty. Journal of Marketing Research, 32-35.

Veloutsou, C. (2015). Brand evaluation, satisfaction and trust as predictors of brand loyalty: the mediator-moderator effect of brand relationships. Journal of Consumer Marketing, 405-421.

Watts, S. A., \& Zhang, W. (2008). Capitalizing on content: Information adoption in two online communities. Journal of the Association for Information Systems, 9(2), 3.

We are Social, (2019). Digital 2019: Global Internet Use Accelerates. Erişim 20 Mayıs 2020, https://wearesocial.com/blog/2019/01/digital-2019-global-internet-use-accelerates

Wixom, B.H. and Todd, P.A. (2005), "A theoretical integration of user satisfaction and technology acceptance", Information Systems Research, Vol. 16 No. 1, 85102.

Wu, C., \& Shaffer, D. R. (1987). Susceptibility to persuasive appeals as a function of source credibility and prior experience with the attitude object. Journal of personality and social psychology, 52(4), 677.

Wu, P. C., \& Wang, Y. C. (2011). The influences of electronic word-of-mouth message appeal and message source credibility on brand attitude. Asia Pacific Journal of Marketing and Logistics, 448-472.

Yu, X., Liu, Y., Huang, X., \& An, A. (2012). Mining online reviews for predicting sales performance: A case study in the movie domain. IEEE Transactions on Knowledge and Data engineering, 24(4), 720-734.

Zboja, J. J., \& Voorhees, C. M. (2006). The impact of brand trust and satisfaction on retailer repurchase intentions. Journal of services marketing, 20(6), 381-390.

Zhao, P., Wu, J., Hua, Z., \& Fang, S. (2019). Finding eWOM customers from customer reviews. Industrial Management \& Data Systems, 129-147. 